\title{
Japan: 2008 Article IV Consultation-Staff Report; Staff Statement; and Public Information Notice on the Executive Board Discussion
}

Under Article IV of the IMF's Articles of Agreement, the IMF holds bilateral discussions with members, usually every year. In the context of the 2008 Article IV consultation with Japan, the following documents have been released and are included in this package:

- $\quad$ The staff report for the 2008 Article IV consultation, prepared by a staff team of the IMF, following discussions that ended on May 22, 2008, with the officials of Japan on economic developments and policies. Based on information available at the time of these discussions, the staff report was completed on June 27, 2008. The views expressed in the staff report are those of the staff team and do not necessarily reflect the views of the Executive Board of the IMF.

- $\quad$ A staff statement of July 21, 2008, updating information on recent developments.

- $\quad$ A Public Information Notice (PIN) summarizing the views of the Executive Board as expressed during its July 21, 2008 discussion of the staff report that concluded the Article IV consultation.

The document listed below will be separately released.

$$
\text { Selected Issues Paper }
$$

The policy of publication of staff reports and other documents allows for the deletion of market-sensitive information.

Copies of this report are available to the public from

International Monetary Fund • Publication Services $70019^{\text {th }}$ Street, N.W. • Washington, D.C. 20431

Telephone: (202) 623-7430 • Telefax: (202) 623-7201

E-mail: publications@imf.org・Internet: http://www.imf.org

Price: $\$ 18.00$ a copy

\section{International Monetary Fund} Washington, D.C. 

INTERNATIONAL MONETARY FUND

JAPAN

\section{Staff Report for the 2008 Article IV Consultation}

Prepared by the Staff Representatives for the 2008 Consultation with Japan

Approved by Daniel Citrin and Adnan Mazarei

June 27, 2008

- This report is based on discussions held in Tokyo during May 13-22. The team comprised Messrs. Citrin (Head), Gordon, Kang, Iizuka, N'Diaye, Sommer (all APD), Mr. Semblat (OAP) and Mr. Frydl (MCM). Messrs. Kotegawa and Yamaoka (both OED) also participated.

- Counterparts. The mission met with Bank of Japan (BoJ) Deputy Governor Nishimura, Vice-Minister of Finance for International Affairs Shinohara, other senior officials, academics, and private sector representatives.

- Context of past surveillance. In recent years, the Fund and the authorities have agreed on the broad policy priorities - pursuing medium-term fiscal consolidation, further strengthening the financial and corporate sectors, and stepping up productivity-boosting reforms. Notwithstanding the progress made, the Fund has advocated that fiscal consolidation and structural reforms proceed at a somewhat faster pace to strengthen growth prospects in the context of population aging and promote an orderly adjustment of global imbalances.

- Japan's exchange rate is market determined. Japan has accepted the obligations of Article VIII. The exchange system is free of restrictions on the making of current international transactions, with the exceptions of those notified to the Fund in accordance with Executive Board Decision 144-(52/51) and UN-sanctioned restrictions on external payments for security reasons. 
Contents $\quad$ Page

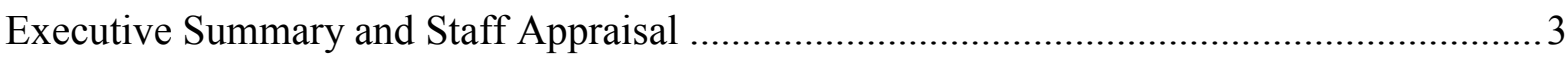

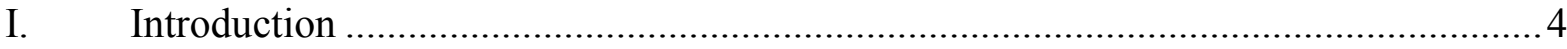

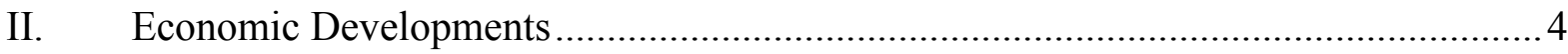

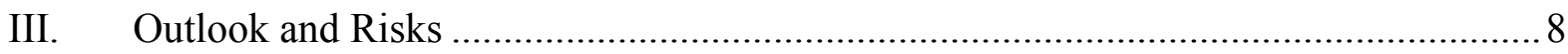

IV. Near-Term Policy Imperatives in an Uncertain Global Environment..........................10

A. Reducing the High Debt Burden ...................................................................... 10

B. Monetary Policy and the Exchange Rate ........................................................... 15

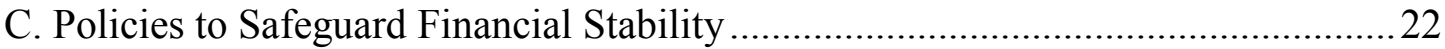

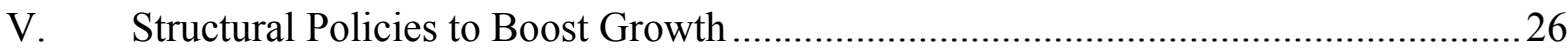

Boxes

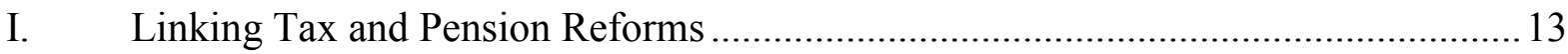

II. Developments Regarding the BoJ's Monetary Policy Framework …………............... 17

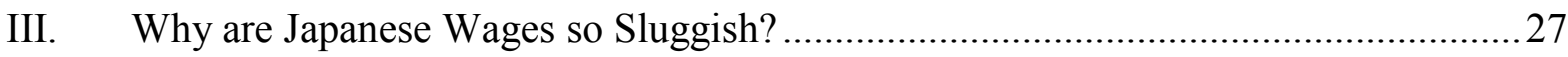

Figures

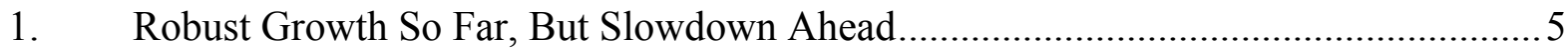

2. Financial Stress Has Moderated Somewhat Since Mid-March......................................

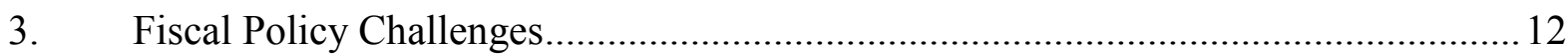

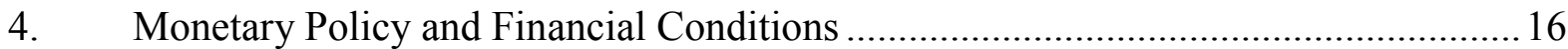

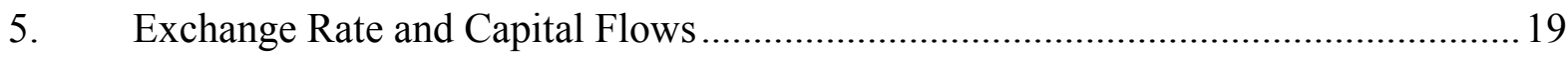

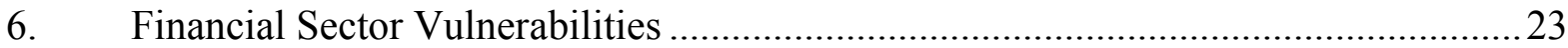

Tables

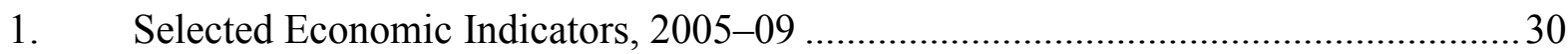

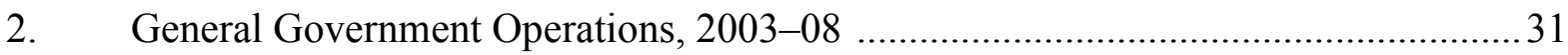

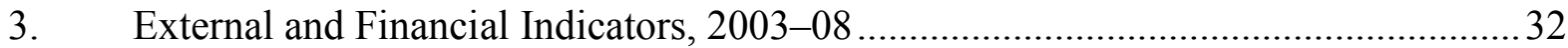

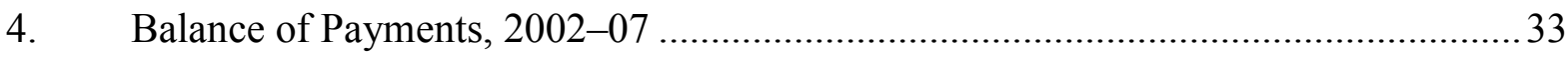

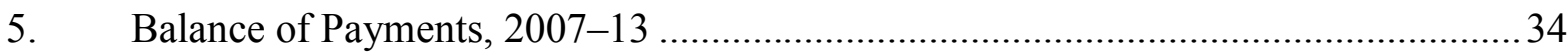

Appendices

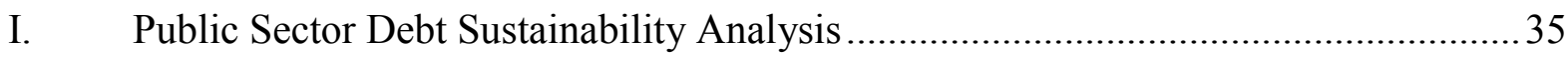




\section{EXECUTIVE SUMmary AND STAFF APPRAISAL}

Outlook and risks. Japan appears headed for a modest slowdown, although there remain risks from the global economy. Subprime fallout has been limited and activity has been supported by strong exports to non-U.S. destinations. GDP growth is expected to moderate to slightly below potential in 2008-09 in line with lower global demand and the less favorable terms of trade. Headline CPI inflation has edged up, reflecting higher commodity prices, but wages remain sluggish, and inflation risks so far appear contained. Risks to the growth outlook have become more balanced in recent months, although considerable uncertainty remains, particularly regarding global commodity prices and their effects on the economy.

Fiscal policy. Strong tax collections and cuts in public works have trimmed the fiscal deficit in recent years, but public debt remains high. The government is targeting a primary deficit (excluding social security) of $1 \frac{1}{2}$ percent of GDP in FY2008 (year begins in April) and is aiming for primary balance by FY2011. Assuming only a slight cyclical downturn, the FY2008 deficit target should be maintained even if tax revenue falls short. Thereafter, a more ambitious strategy would be desirable so as to place public debt on a firmly downward path: beginning in FY2009, staff recommends deficit cuts of $3 / 4$ percent of GDP per year on average.

Tax reform. With limited scope for further expenditure cuts, fiscal consolidation will require comprehensive tax reform including raising the consumption tax. The tax reform debate has moved slowly. Nonetheless, the government's FY2009 plan to end earmarking of gas taxes is welcome. The government also intends to increase its contribution to the basic pension, which will require additional revenue. In light of these plans, various tax reform options are on the table. A consumption tax hike may become more palatable if it is linked to the need to fund social security spending and this opportunity to raise the consumption tax rate should be seized.

Monetary policy and the exchange rate. Underlying inflation is still about zero and the BoJ can afford to hold interest rates steady until concerns over domestic activity and the global economy have eased. However, prices have begun to rise, and to guide inflation expectations, the BoJ is rightly improving communication about the future conduct of monetary policy. The yen remains market-determined and has appreciated by about 10 percent in real effective terms since mid-2007, but staff estimates suggest that it remains undervalued relative to its longer-term equilibrium.

Financial sector policies. Japan was not a major subprime player and the financial system has escaped serious damage, with the BoJ's flexible liquidity management keeping money markets stable. The authorities remain vigilant to risks from further global market disruptions, as well as from a slowing economy. Banks' end-year results already incorporate additional information on structured holdings as called for by the Financial Stability Forum (FSF). Bolstering capital cushions and improving risk management would help to further strengthen the financial system and enhance financial intermediation. 
Structural reforms. It would be highly desirable to reinvigorate structural reforms. Priorities remain to increase labor market flexibility and promote competition through greater market opening and further deregulation in sectors such as agriculture and services. Such reforms could lift medium-term growth prospects and contribute to the resolution of global imbalances.

It is recommended that the next Article IV consultation take place on the standard 12-month cycle.

\section{INTRODUCTION}

1. The economy has weathered the global financial turbulence fairly well, but the terms of trade loss has weakened confidence. Household spending growth has slowed from its peak in 2006, while corporations have scaled back investment. Both domestic and external factors have contributed to slowing momentum and deteriorating sentiment. Domestic factors include the poorly executed tightening of the building code last year and sluggishness in wages. External factors relate to moderating foreign demand, high fuel and food prices, the appreciation of the yen, and the global market turmoil. After four years of growth above potential (estimated at about 1.7 percent), a mild slowdown is expected in 2008-09.

2. Political developments have also hurt sentiment. Reforms have slowed amid concerns over widening dualities between regions and sectors, and between regular and nonregular workers. At the same time, the opposition's control of the Upper House has weakened the ruling LDP coalition's position and Prime Minister Fukuda's approval rating has slumped. Feuding in the Diet in March left the BoJ without a Governor and led to a lapse of the gasoline surcharge. In April, however, a new Governor was appointed and the gasoline surcharge was reinstated.

\section{ECONOMIC DEVELOPMENTS}

\section{The economy has shown resilience to the U.S. slowdown, although inflation has picked up.}

- $\quad$ Activity. GDP grew by 2.1 percent in 2007, down from 2.4 percent the previous year. Domestic demand weakened significantly, mostly owing to lower private consumption growth and the regulatory-induced slump in construction activity. In Q1 2008, GDP growth was strong at 4 percent (q/q, s.a.a.r.), led by robust export demand, particularly from the rest of Asia and oil-producing countries. A recovery in residential investment also provided support to growth. However, some of the strength in Q1 may reflect statistical leap year effects, and leading indicators, such as the BoJ Tankan survey, point to a slowdown ahead (Figure 1). 
Figure 1. Japan: Robust Growth So Far, But Slowdown Ahead

The economy has grown above potential ...

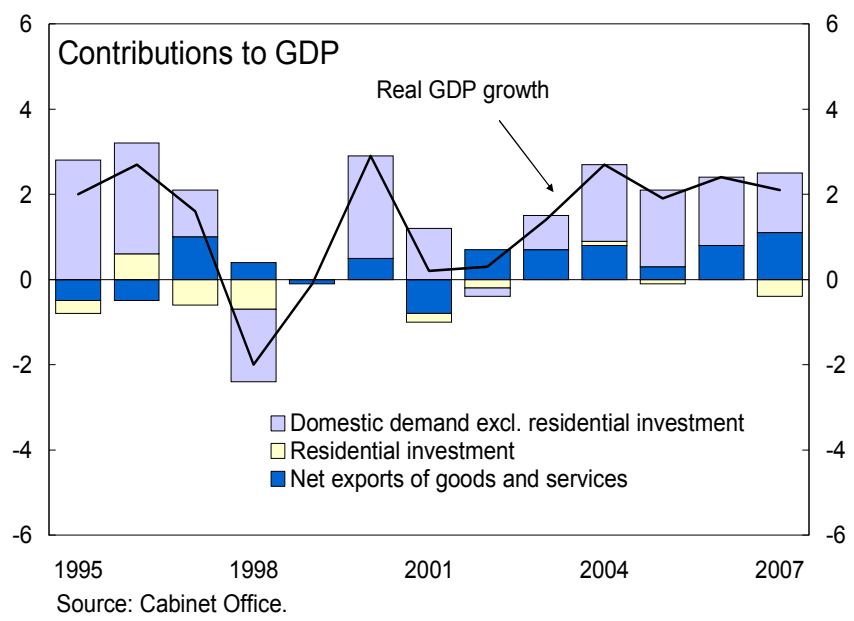

However, confidence has deteriorated for both consumers ...

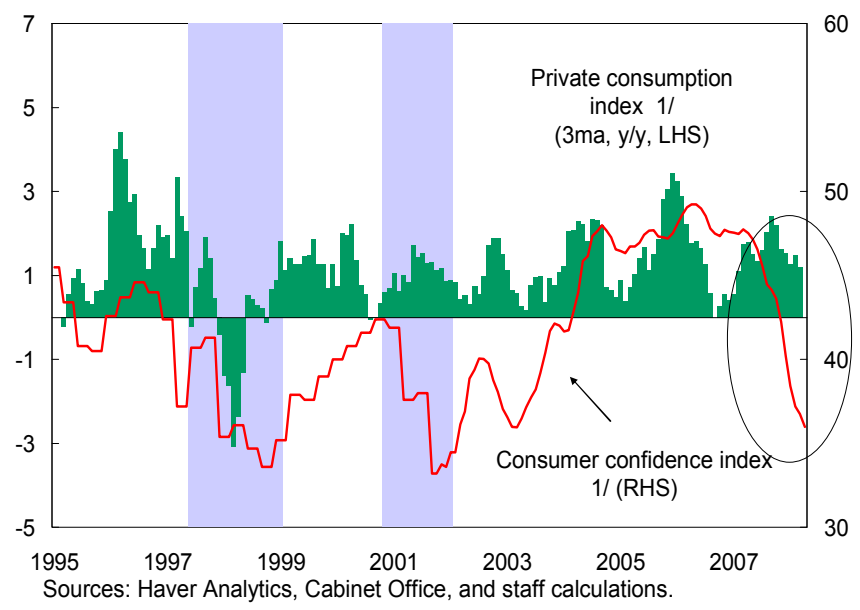

... while industrial production has recently stagnated.

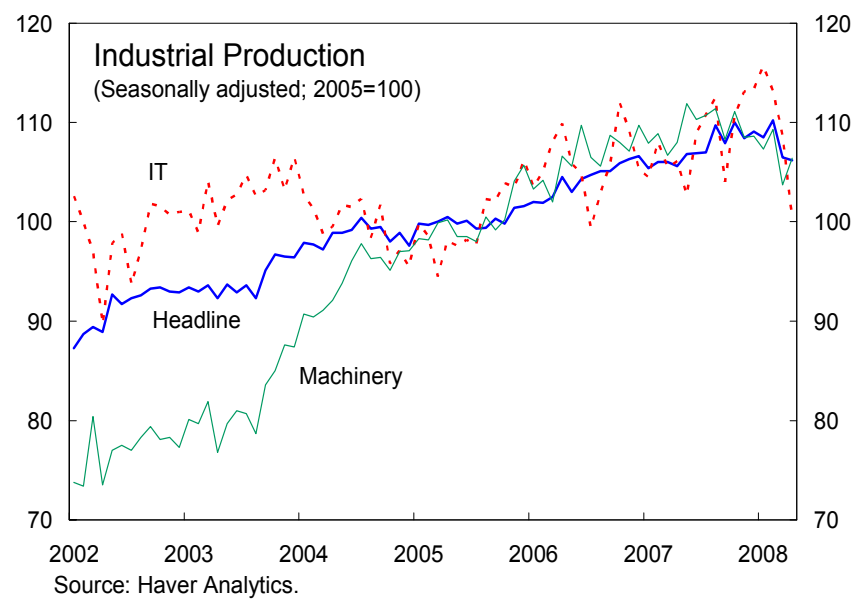

... driven by exports to non-U.S. destinations.

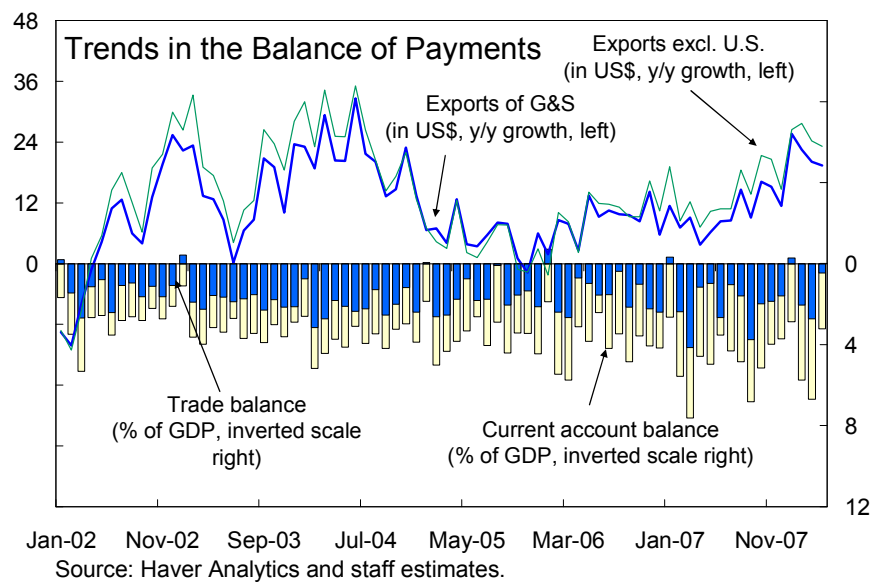

... and businesses ...

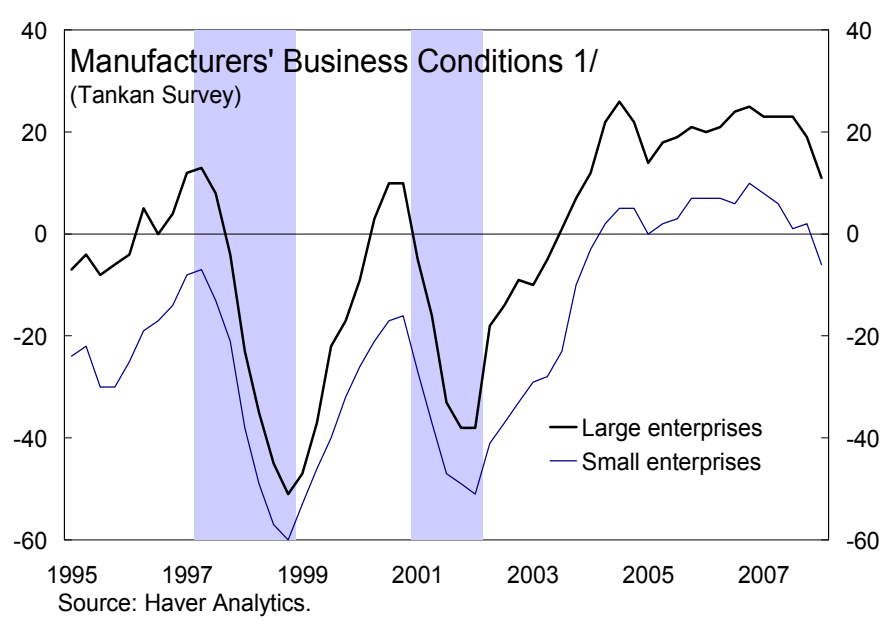

Meanwhile, headline inflation has accelerated, but underlying inflation remains low.

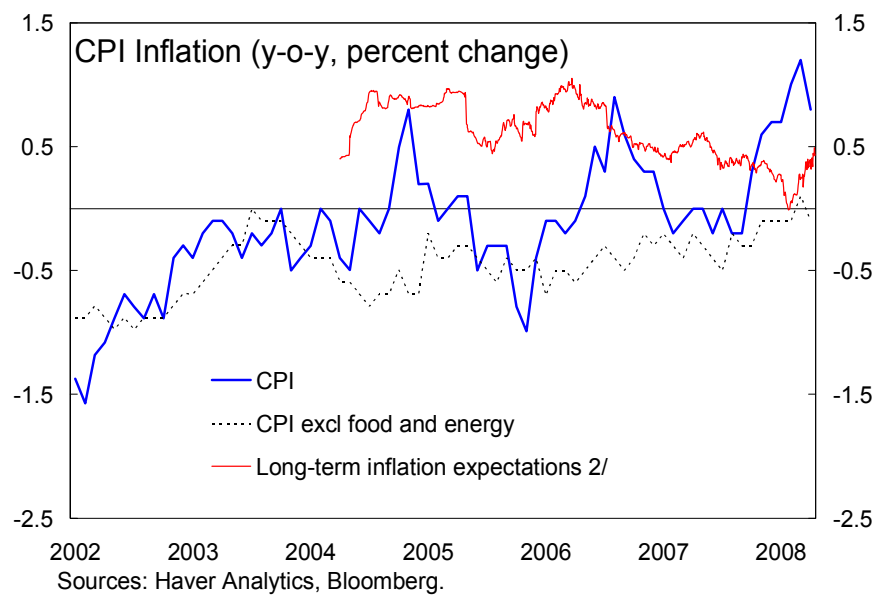

1/ Shaded area denotes recession period.

2/ The daily data on inflation expectations are calculated from 10-year inflation-indexed bond yields. 
- Inflation. CPI inflation has recently been running at about 1 percent, well above last year's levels, with firms starting to pass through cost increases to consumers. Firms have also responded to higher input prices by granting limited wage increases and unit labor costs continue to fall on a year-on-year basis. Core inflation, which by staff's definition excludes both fuel and food prices, remains about zero. Measures of inflation expectations have various flaws, but suggest that short-term inflation expectations have risen, while longer-term expectations remain contained.

- $\quad$ Current account balance. The external surplus rose to 4.8 percent of GDP in 2007 on the back of strong export demand and a continued surge in investment income. In Q1, the trade balance narrowed substantially owing to the large deterioration in the terms of trade, while income inflows continued apace.

- $\quad$ Exchange rate. The yen has appreciated against major currencies, particularly the U.S. dollar through March 2008, supported by an unwinding of carry trades and the large current account surplus. Outflows by Japanese investors continued to provide an offset. While the yen has more recently begun to weaken again, the real effective exchange rate has risen about 10 percent since mid-2007.

4. The fallout from the global market turmoil on the financial system has also been limited (Figure 2).

- $\quad$ Money markets. The spread between 3-month LIBOR and the overnight index swap (OIS) rate has widened, but to a lesser extent than in the United States and Euro area and with considerably less volatility. The more muted impact in Japan reflects the banking system's lower exposure to subprime and other securitized products. Larger and more frequent liquidity operations by the BoJ, including for same-day settlement, have also helped to stabilize money markets.

- $\quad$ Financial Institutions. Subprime-related losses for banks, including their securities affiliates, have risen to $\$ 8$ billion, but still remain well within operating profits and capital. ${ }^{1}$ Profits of nonbank lenders relying on wholesale financing, such as consumer finance companies, have been affected by higher funding costs due to the financial turmoil and the introduction of tighter interest rate ceilings under the new consumer finance law. However, the size of these lenders relative to banks is small.

- $\quad$ Stock markets. The Japanese stock market has been highly volatile and fell sharply in early 2008, driven by heavy selling by foreign investors related in part to the need to

\footnotetext{
${ }^{1}$ Official data on losses made by other securities and insurance companies have not been released, but a recent market estimate indicates total losses of $\$ 14$ billion when such institutions are included. A Selected Issues paper assesses the impact and lessons of the global financial turmoil for Japan.
} 
Figure 2. Japan: Financial Stress Has Moderated Somewhat Since Mid-March

Subprime losses of banks have increased but remain small compared to profits and capital.

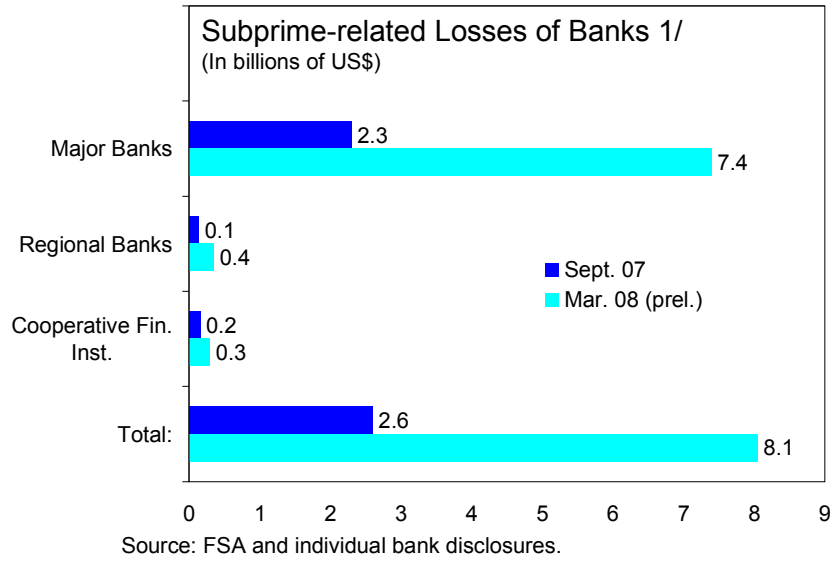

Money markets spreads remain smaller than in the U.S. and Eurozone ...

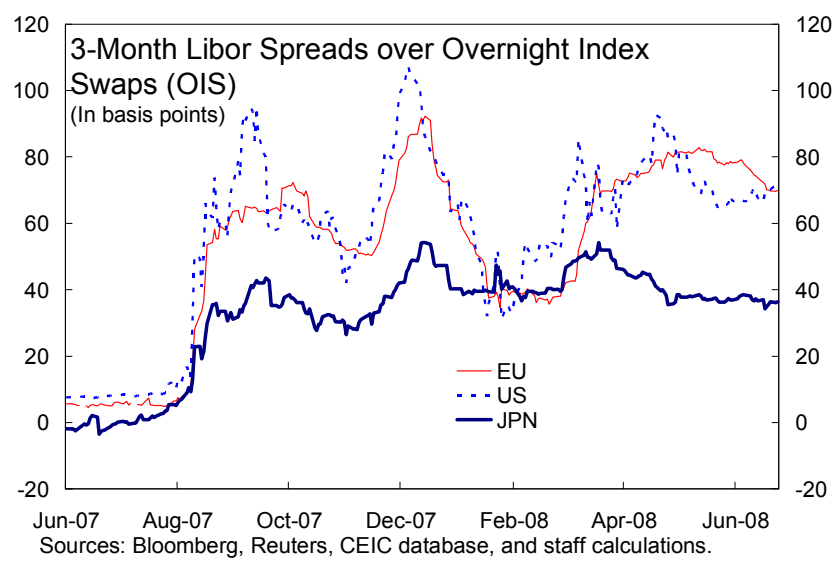

... and the risk premia in the FX swap markets have also come down.

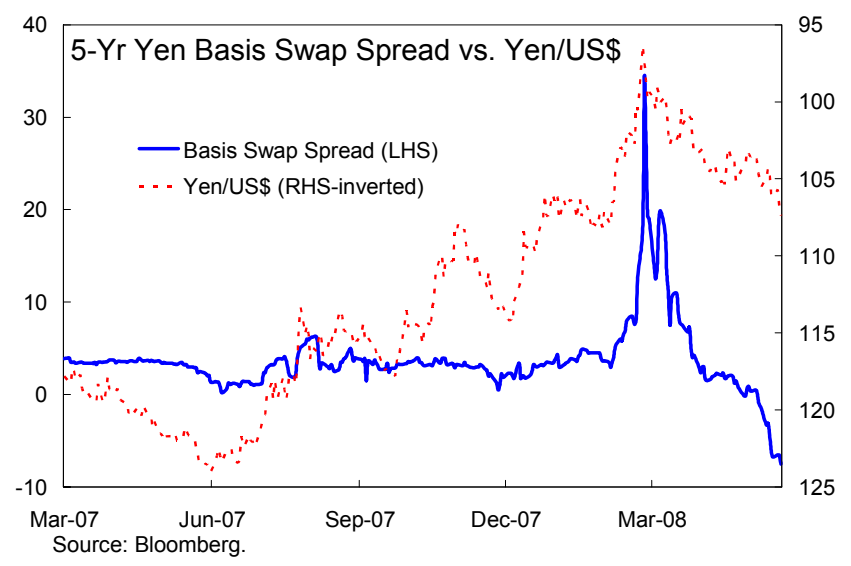

Japanese equity markets fell sharply but have recovered about half of their losses.

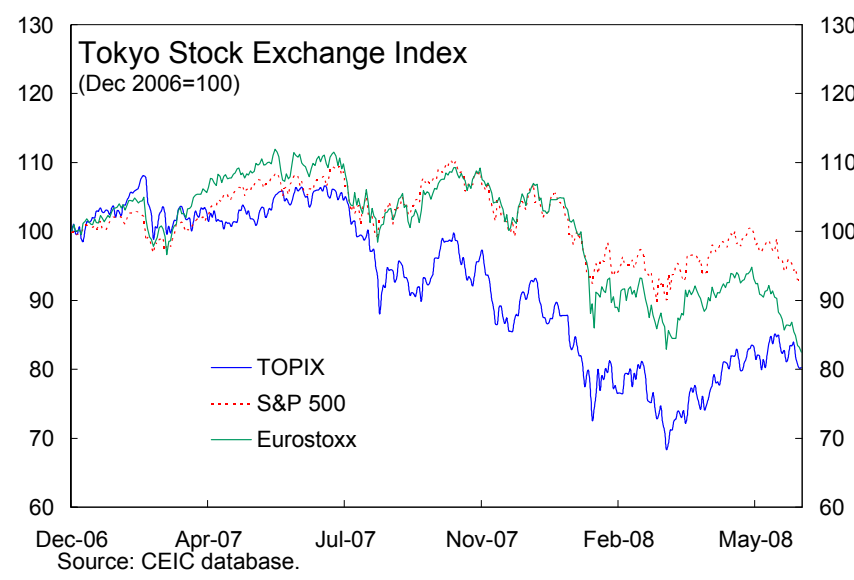

... while CDS spreads have narrowed somewhat since their midMarch peak ...

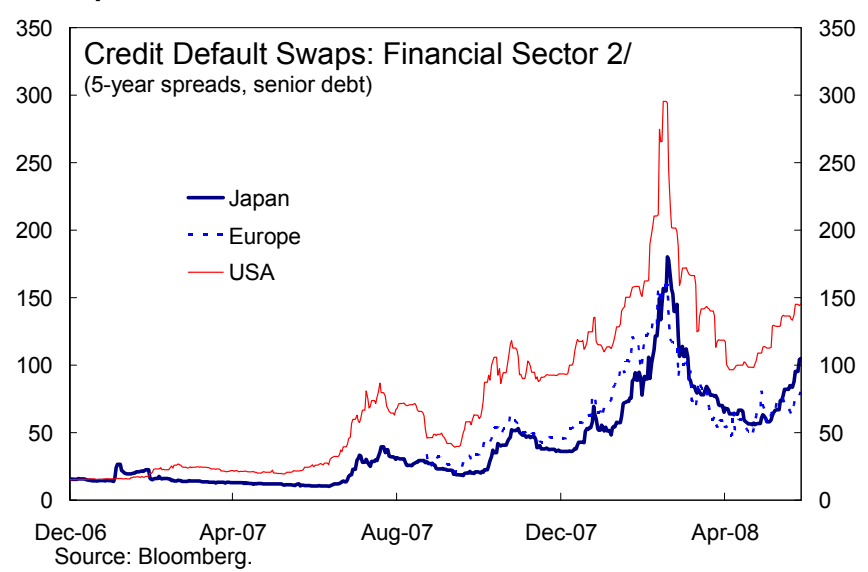

Lending conditions have tightened mostly for low-rated companies.

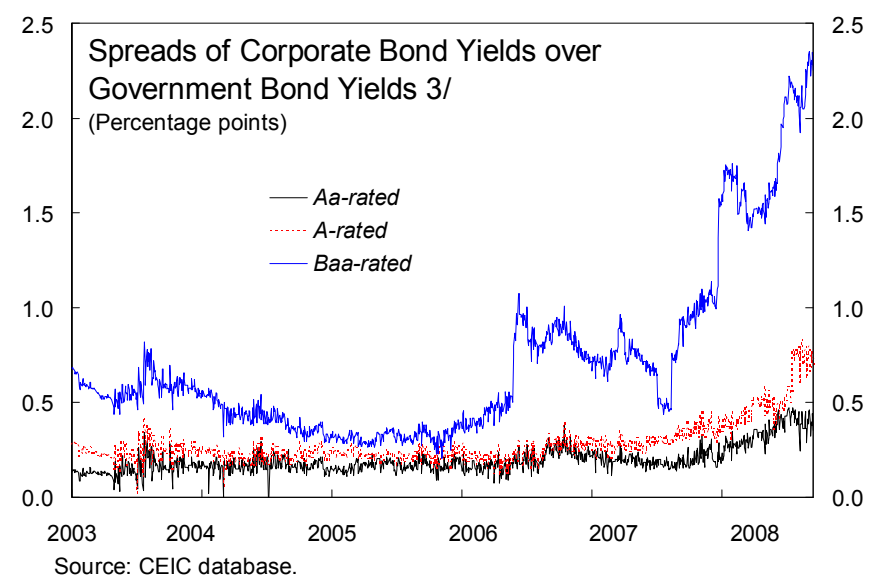

1/ Accumulated subprime-related losses for Japanese deposit-taking institutions. Tier 1 capital as of end-March 2008 was $\$ 477$ billion while core operating profits in FY2007 were $\$ 58$ billion.

2/ iTraxx Financial for Europe; average of eight major banks, securities, and insurances for Japan; and average of five major commercial and investment banks for the US.

3/ Bond yields are with 5-year maturity. The ratings are of Moody's. 
generate liquidity as a consequence of global credit market pressures. After falling by nearly 30 percent during FY2007 (year begins April), the TOPIX recovered about half of its losses through early June, as global concerns over systemic risk eased.

\section{OUTLOOK AND RISKS}

\section{Staff's Assessment}

\section{The economy appears headed for a soft landing, notwithstanding downside risks.}

- $\quad$ Baseline. Staff project GDP growth to moderate to around $1 \frac{1}{2}$ percent in 2008 and 2009, somewhat below potential. Private consumption and business investment are likely to slow, offset in part by a turnaround in construction and robust exports to emerging markets. ${ }^{2}$ Headline CPI inflation is expected to rise to around 1 percent in 2008, reflecting higher food and fuel prices, but should moderate somewhat next year as pressure from commodity prices dissipates. The current account surplus is expected to narrow to 4 percent of GDP in 2008.

- $\quad$ Risks. Compared to several months ago, the risks to the outlook are more evenly balanced, as concerns over a global credit squeeze have eased somewhat and growth in emerging markets and oil-producing countries has held firm. Even so, the outlook is still subject to considerable uncertainty surrounding the depth of the U.S. slowdown and future developments in financial conditions, while surging commodity

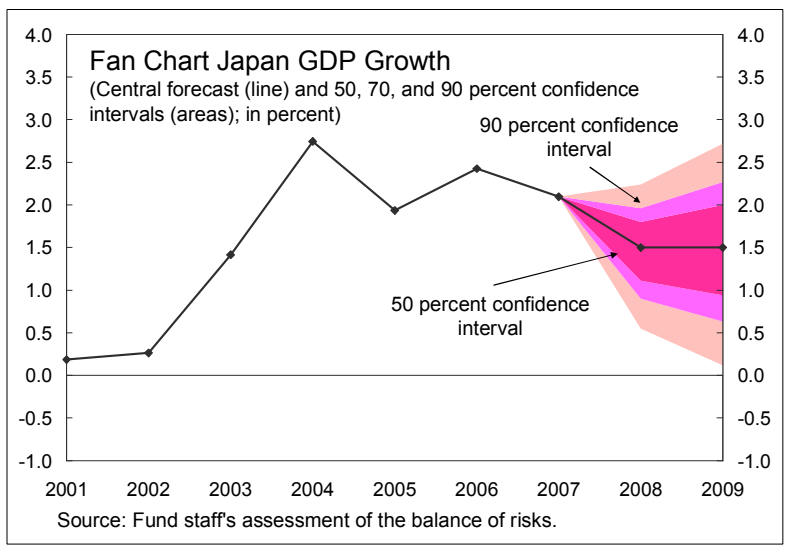
prices are already weighing on corporate profits and household incomes.

6. Given the uncertain outlook, significant deviations from the baseline cannot be ruled out. These include a global recession scenario and higher-than-expected global inflation in the context of a slow global recovery:

\footnotetext{
2 The share of Japan's exports to North America and Western Europe has declined from 56 percent in 1990 to 49 percent in 2000 and 36 percent in 2007. Export shares to Asia have risen from 31 percent in 1990 to 41 percent in 2000 and 48 percent in 2007.
} 
- $\quad$ Global recession. A downside scenario, such as that considered in the April 2008 $W E O$ in which annual growth in the United States falls to $-13 / 4$ percent in 2009 (and global growth declines to $2 \frac{1 / 4}{4}$ percent), would likely put the Japanese economy on the edge of a "shallow" recession. ${ }^{3}$ If such a global slump were accompanied by renewed financial turmoil that further tightens credit conditions, confidence and domestic demand in Japan could weaken by even more. Even with a monetary easing in Japan, inflation could fall back into negative territory. Given Japan's increased trade and financial integration with the rest of Asia, there would be negative spillovers effects on the region. Growth in emerging Asia would fall by $1 \frac{1 / 4}{4}$ percentage points.
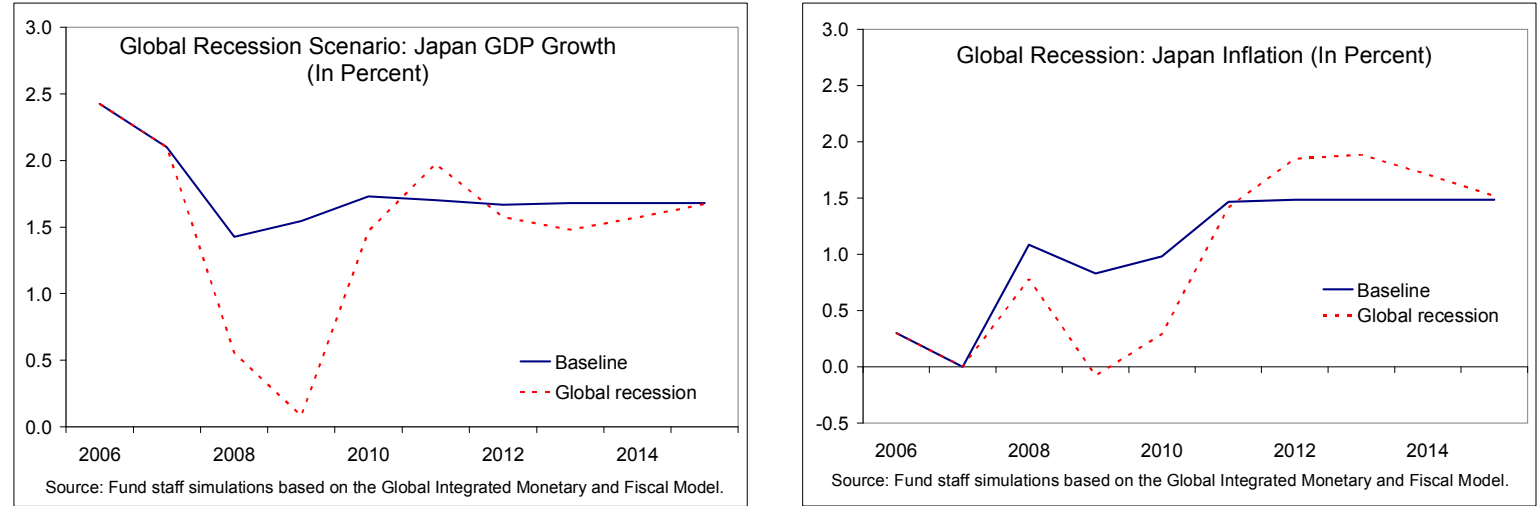

- Global inflation. International commodity prices could continue to soar, raising inflation expectations and fanning generalized inflation. Assume for illustration a supply shock that raises global inflation by about one percentage point in 2009 , eliciting a round of monetary tightening across countries and requiring a period of below-potential global growth. If monetary tightening was to lag in Japan, perhaps because the growth outlook still appeared very uncertain, staff simulations show that inflation in Japan could rise to as high as 2 percent by 2010. Alternatively, if monetary policy was to be tightened at the same time as in other countries, the pick-up in
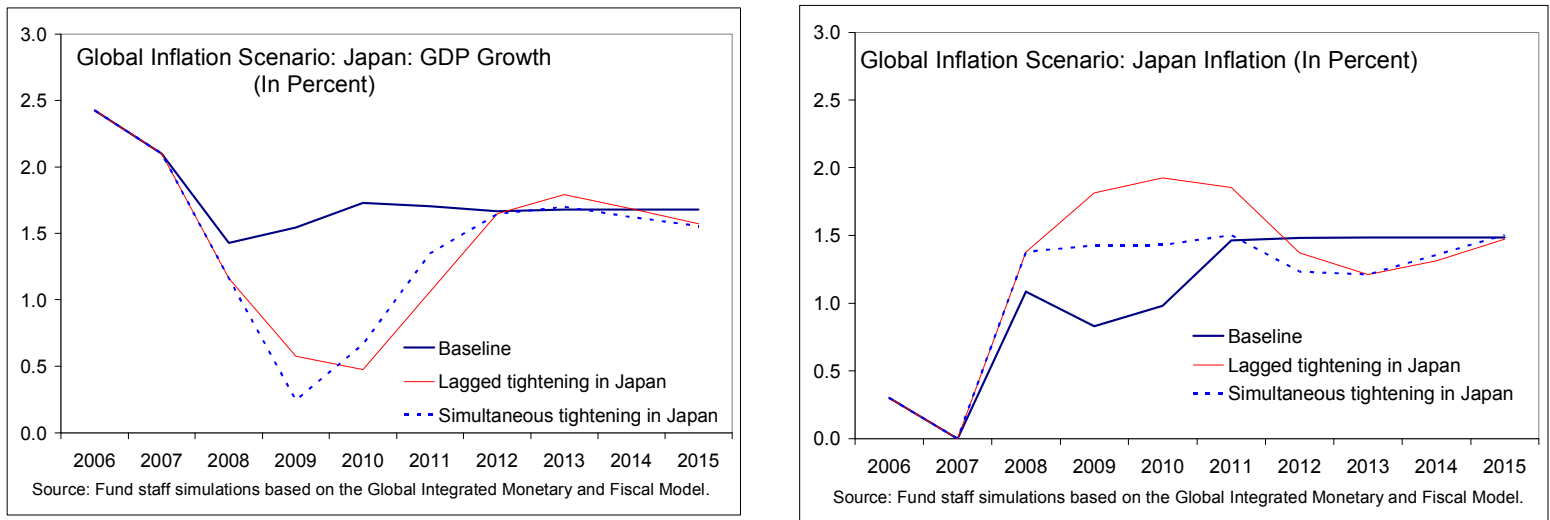

\footnotetext{
${ }^{3}$ The global recession scenario assumes a temporary decline in consumption and investment from tightening credit conditions, a decline in long-term U.S. productivity growth, and a repricing of risk worldwide that entails a shift away from U.S. assets.
} 
inflation would likely be smaller. Growth would decline by a little more initially, but would also recover faster.

\section{The Authorities' Views}

7. The authorities had a similar assessment of the outlook and risks.

- Near-term outlookfor growth and inflation. In its semi-annual Outlook in April, the BoJ noted that it expected GDP growth to slow this fiscal year to around potential. Core inflation (by the BoJ definition, which only excludes fresh food) was projected to accelerate to around 1 percent, mainly driven by higher fuel and other commodity prices.

- Risks. The BoJ considered rising demand from emerging markets and commodityproducing countries to have so far more than offset the adverse effects of the deterioration in the terms of trade, but there were risks to the near-term outlook from weaker global growth and financial markets, higher commodity prices, and deteriorating business confidence. Overall, the risks were judged to be tilted slightly to the downside in 2008, but more balanced in 2009.

\section{NeAR-Term Policy IMPERATIVES IN AN UNCERTAIN GLOBAL ENVIRONMENT}

Against the forecast of a soft landing, fiscal policy should focus on medium-term challenges, while given the considerable uncertainty in the outlook, the current accommodative setting for monetary policy appears appropriate. Financial sector policies should continue to guard against spillovers from global markets and risks from slowing domestic activity.

\section{A. Reducing the High Debt Burden}

\section{Background}

8. Fiscal consolidation has paused this year and the authorities' medium-term plans fail to build on recent progress.

- $\quad$ FY2007 outturn. Buoyant tax revenue and public investment cuts reduced the general government primary deficit (excluding social security) to around $1 / 2$ percent of GDP in FY2007, down from 3 percent of GDP in FY2005. The net public debt ratio is estimated to have risen to about 90 percent of GDP in FY2007.

- $\quad$ FY2008 budget. This year's budget targets a broadly unchanged primary deficit with a slight increase in total expenditures due to higher social security costs and lower tax buoyancy. The gasoline surcharge and other taxes that expired at end March were quickly reinstated with minimal effect on the FY2008 budget. The revenue is still 
earmarked for road construction and maintenance, but the authorities intend to discontinue this practice from FY2009.

- $\quad$ Authorities' medium-term plans. The authorities' revised fiscal plans continue to target a primary balance (excluding social security) by FY2011. This plan assumes expenditure cuts of $¥ 11.4-14.3$ trillion $\left(2^{1 / 4-2}-2 / 4\right.$ percent of GDP), but no major revenue measures. Under staff's lower growth projections, the authorities' plans would be insufficient to prevent net public debt from continuing to trend up (Figure 3).

- $\quad$ Consumption tax and social security reform. To address inequities in the pension system, consideration is being given to extending the coverage of the basic old-age pension, the National Pension (NP), irrespective of past premium payments and linking an increase in the consumption tax to the need to finance the pension program (Box I). An immediate challenge is to finance a planned increase in the government's contribution to the NP system from $1 / 3$ to $1 / 2$ in FY2009 at a cost of about $¥ 2 \frac{1}{2}$ trillion ( 0.5 percent of GDP). This is equivalent to increasing the consumption tax rate by 1 percentage point to 6 percent.

\section{Policy Issues and Staff Views}

\section{Fiscal policy should remain focused on reducing the high debt burden and addressing the needs of an aging population.}

- $\quad$ Near-term fiscal stance: The FY2008 budget's broadly neutral stance seems unambitious given that public debt is still so high and only a mild slowdown is expected. In the event that revenues fall short of the budget target, it would be prudent to constrain spending in order to prevent undermining fiscal consolidation. At the least, an expansionary supplementary budget should be avoided this year.

- $\quad$ Near-term fiscal stance under a global recession scenario: If growth were to slow sharply, the automatic stabilizers could be allowed to work, although their size is subject to uncertainty. The scope for more active fiscal policy is limited by the high debt and the unsuccessful experience with stimulus spending in the 1990s.

- $\quad$ Pace of consolidation over the medium term. Starting in FY2009, the staff recommends an adjustment of the primary balance (excluding social security) of about $3 / 4$ percent of GDP per year or about $1 / 2$ percent of GDP more than in the authorities' reference path. If maintained on average through FY2013, this would lead to a primary surplus of 13/4 percent of GDP in FY2013 and put the public net debt ratio firmly on a downward path (Appendix I). Faster consolidation could help to dispel uncertainties over the pension system that may be weighing on consumption. Restoring Japan's 
Figure 3. Japan: Fiscal Policy Challenges

Fiscal consolidation is ahead of the authorities' schedule ...

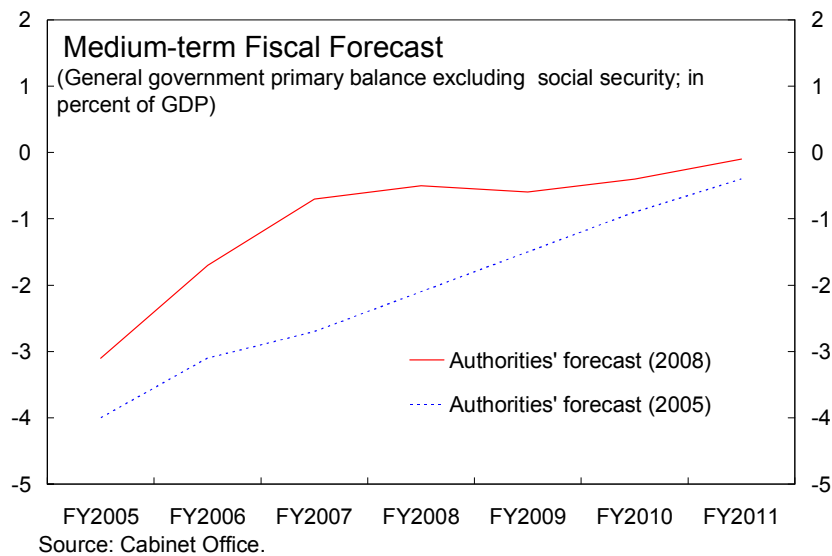

Nonetheless, the public net debt ratio is still rising...

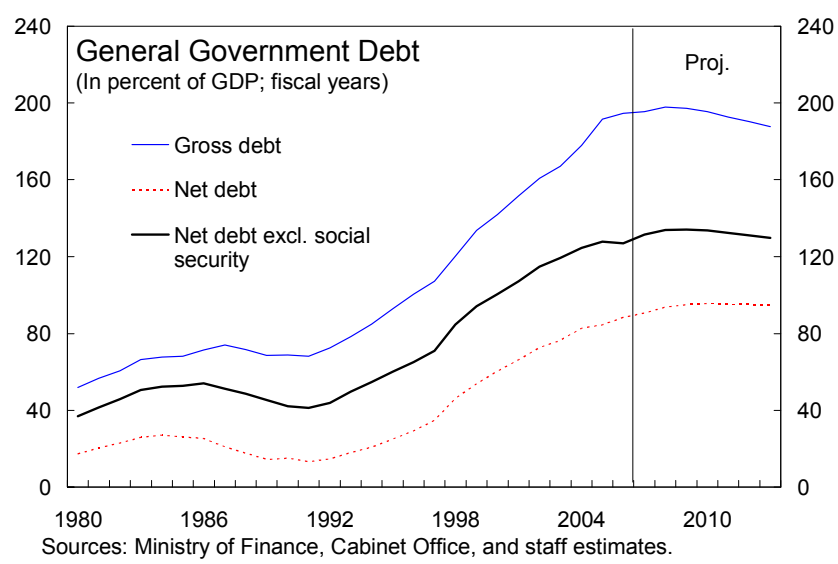

Revenue measures will be necessary ...

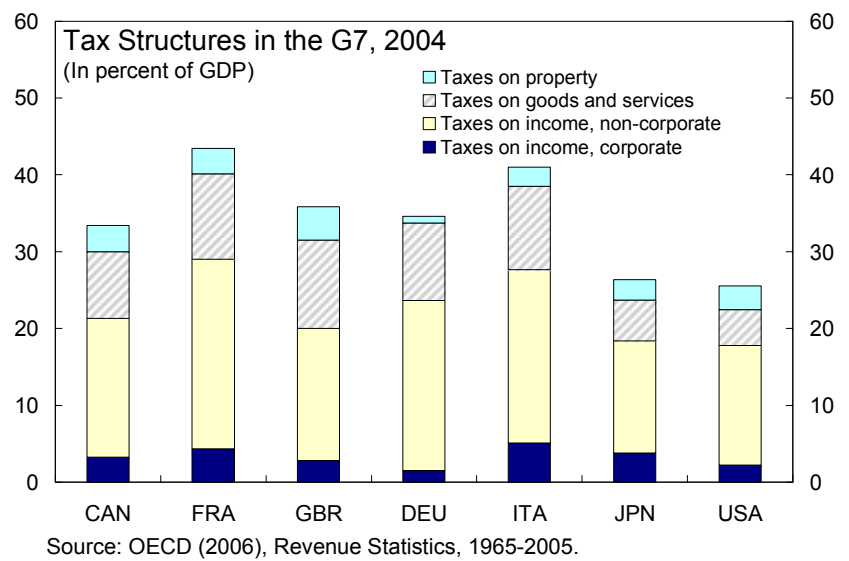

... in part reflecting tight expenditure control and buoyant revenues.

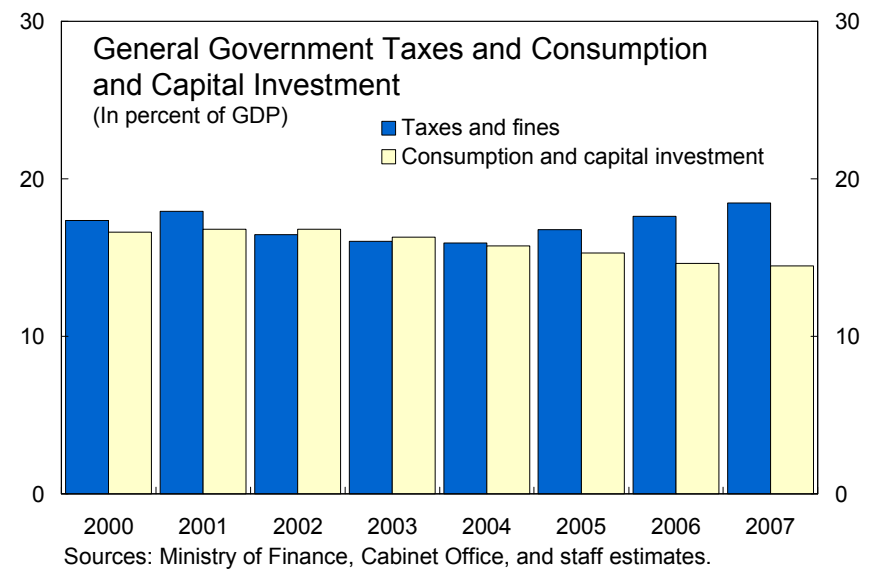

... and expenditure cuts may be reaching their limits given rapid population aging.

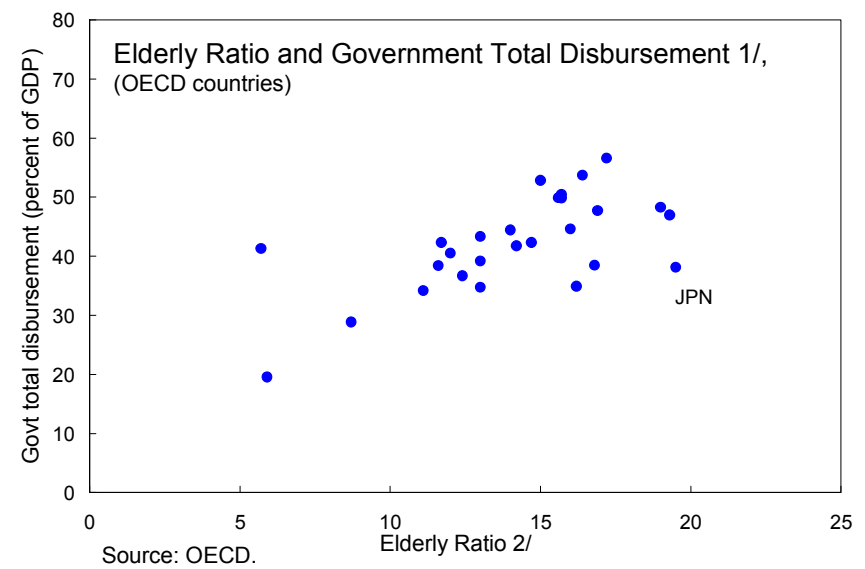

... to put public debt ratios on a firmly downward path.

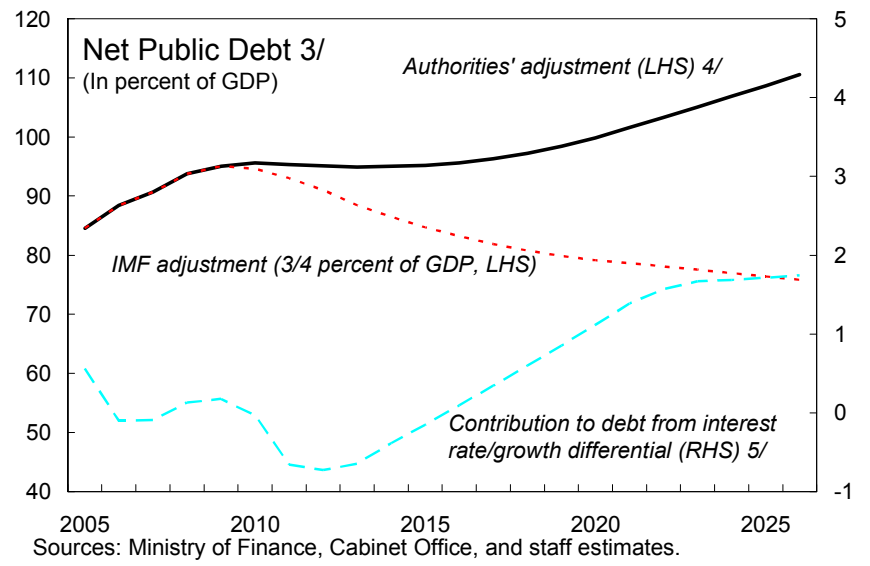

1/ 2004 data for elderly ratio and 2005 data for government disbursement.

2/ Population over 65 years as percent of total.

3/ Based on staff's macroeconomic forecast. See Annex I for a comparison with the authorities' projections.

4/ Data are from the latest WEO submission through FY2013. Projections are based on the assumption that the authorities will maintain the primary balance and interest rate/growth differential will gradually converge to G7 average since 1990 .

5/ Based on the authorities' adjustment path, three-year moving average. 


\section{Box I. Linking Tax and Pension Reforms}

Japan's social security system is under scrutiny. Concerns have arisen about whether the pension system provides a sufficient safety net given Japan's rapid aging and widening economic disparities. This has led to the beginning of a public debate on revamping the pension system. At the same time, government health spending is growing rapidly as Japan ages. Discussions are still at an early stage, but have centered around proposals to link an increase in the consumption tax to the need to fund higher social security spending. ${ }^{1}$

Reforms introduced after the pension review in 2004 reduced pressures on the pension scheme, but equity concerns remain. Pension reforms included limiting increases in contribution rates; indexing of benefits to socio-economic variables; and a planned increase from FY2009 in the government's contribution to the National Pension (NP) from $1 / 3$ to $1 / 2$. These measures have helped to reduce somewhat the inequality in the intergenerational distribution of net pension benefits that has arisen under a PAYG system from an aging society. This inequality had created incentives in Japan for the younger generation to opt out of the pension system, a tendency that may have

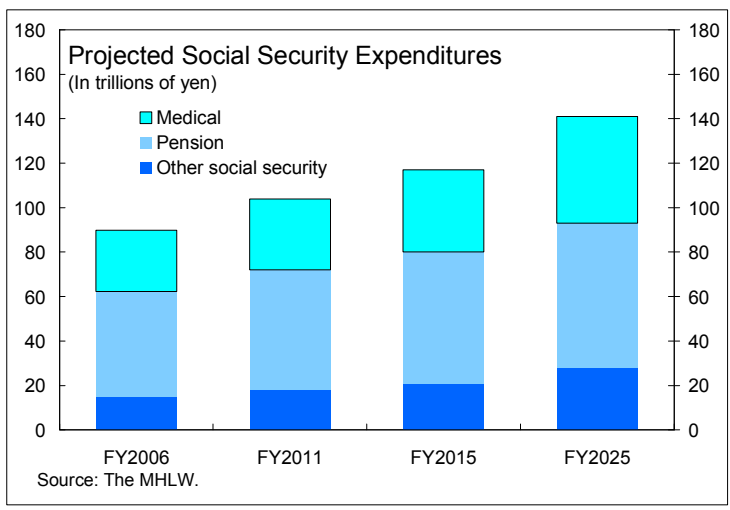
been reinforced by concerns about mismanagement of a large number of records that was revealed in Parliament in 2007. In addition, with the number of marginalized workers (e.g., non-regular workers, workers without past pension payments) also rising, concerns about the limited coverage of the pension system have mounted.

\section{The Cabinet has set up a Committee on Social Security Review to discuss a broad range of social security issues. An early proposal identified a one percentage point hike in the consumption tax rate (currently 5 percent) as a means of financing the planned increase in the government's contribution to the NP. New proposals under consideration envisage an additional increase in the rate of consumption tax by 6-12 percentage points over time to finance the entire NP (while abolishing pension premiums and corporate matching payments) and to extend coverage to those who have opted out of the}

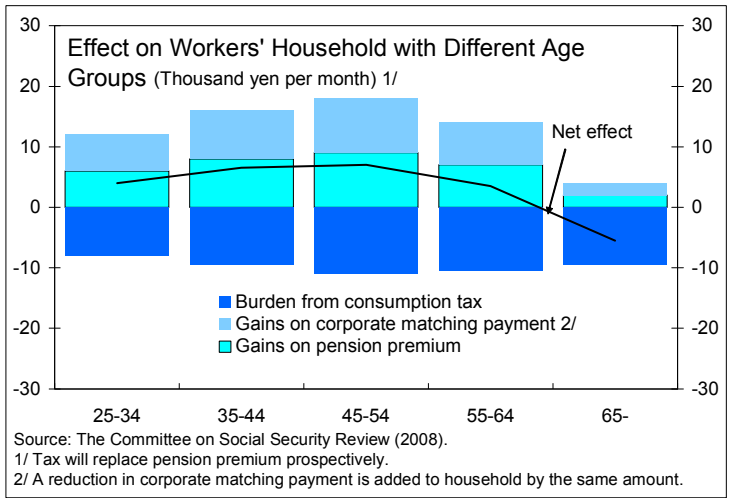
current system. These reforms would help improve the current inter-generational inequality arising from the pension system (Chart). Other pension reforms such as increasing the retirement age and promoting labor market attachment are also under discussion.

The proposals may serve as a vehicle to achieve political support for a consumption tax increase. In 2006, proposals were floated to raise the consumption tax rate as part of a general fiscal consolidation strategy that also involved sizable medium-term expenditure reductions, but did not gain traction. However, taxpayers may be more likely to accept a tax hike if framed in terms of the need to finance social security expenses. In addition, such a reform would alleviate concerns over life after retirement by providing a basic pension to the elderly on more generous terms.

That said, difficult tasks remain in the design. Managing a smooth transition to the new system will be challenging. Japan's pension system has been premium-based for decades and it will be particularly important not to overly penalize those who have paid and continue to pay premiums. Other challenges include monitoring individual income for means testing and coordination between the pension and tax agencies. And, finally, since the coverage of the NP scheme would be expanded, it will be critical to ensure that consumption tax increases are sufficient to cover higher spending.

${ }^{1}$ Possible changes in pension financing are analyzed in a Selected Issues paper. 
fiscal position would also strengthen medium-term growth prospects for the global economy. ${ }^{4}$

\section{Expenditure cuts are nearing their limit and further fiscal consolidation will require tax measures, including raising the consumption tax.}

- Tax reform. A comprehensive reform of the tax system would be desirable to improve efficiency and secure fiscal sustainability. ${ }^{5}$ The proposed ending of earmarking gasoline taxes to road construction in FY2009 is welcome and would support the government's plan to continue reducing public works by 3 percent a year.

- $\quad$ Pension financing reform. Proposals to link an increase in the consumption tax to social security funding have some merit given that this may be a politically palatable way to strengthen the fiscal position (Box I). Such a reform could also help address concerns over inequality in net pension benefits between generations, as well as between those covered and not covered by the system.

- $\quad$ Strengthening social security. Significant parametric reforms of the pension system were introduced following the five-yearly review conducted in 2004. While the debate over pension financing options is now commanding more attention, the next actuarial valuation of the pension system scheduled for 2009 provides an opportunity to assess whether additional reforms such as increasing the retirement age are necessary to support medium-term fiscal sustainability.

\section{The Authorities' Responses and Policy Intentions}

11. The authorities reaffirmed their commitment to fiscal consolidation, but stressed the difficulty of doing more than currently planned.

- Near-term fiscal stance. The authorities recognized that the budget outlook was subject to uncertainty, and should revenue fall short, were unsure to what extent they could reduce expenditure to meet the FY 2008 budget. The authorities also wondered why the Fund's recent advice to member countries to allow full play to the automatic stabilizers did not apply. Staff responded that the baseline scenario was for only a moderate decline in growth and Japan's fiscal problems seemed particularly pressing.

- $\quad$ Pace of consolidation over the medium term. The authorities remain committed to achieving primary balance (excluding social security) by FY2011. While the growth assumptions underlying the medium-term plans might be optimistic, they noted that it

\footnotetext{
${ }^{4}$ The global implications of fiscal consolidation in Japan were analyzed in IMF country report 06/276.

${ }^{5}$ The options for comprehensive tax reform in Japan are outlined in Basic Idea for Fundamental Reform of Tax System, Tax Commission, November 2007 (available at www.mof.go.jp/english/tax/e0711a.pdf).
} 
would be difficult to accelerate the pace of fiscal consolidation given the need for additional social security outlays. Fiscal plans also had to recognize that there was a significant body of political opinion that put economic growth ahead of fiscal consolidation, especially given concerns over increased dualities.

- Reform options. Terminating the earmarking of gasoline tax revenue would facilitate fiscal consolidation by allowing financing for road-related spending to be moved to social security spending. While there would be opposition, the proposal might lead to a more general political discussion of tax reform options. The plan to raise the government's funding share for the basic national pension program in FY2009 also added immediacy to the tax reform debate and the authorities were hopeful that a comprehensive reform involving a hike in the consumption tax would soon be initiated.

\section{B. Monetary Policy and the Exchange Rate}

\section{Background}

12. Monetary policy is accommodative and inflation risks seem contained (Figure 4).

- $\quad$ Monetary policy stance. With underlying price pressures and domestic demand weak, the BoJ has kept the policy rate unchanged at 50 basis points since February 2007, implying a drop in real interest rates given the uptick in inflation.

- $\quad$ Market expectations. Core inflation (excluding fresh food) is now close to the center of the "understanding" of price stability of between zero and 2 percent (Box II). Since mid-April, the market has changed its assessment of the future course of monetary policy, pricing in about a 40 percent chance of a rate hike by end-2008, compared to the earlier expectation of a rate cut.

- $\quad$ Asset prices. Land prices rose by 1.7 percent in 2007, mainly in large metropolitan areas and commercial sites, but have lagged nominal GDP on a cumulative basis since 1970. Entrenched expectations of a continued rise in land prices are absent according to the latest BoJ opinion surveys.

- $\quad$ Liquidity management. The BoJ has a flexible monetary management system and accepts a wide range of collateral, including $\mathrm{ABCPs}$, and extends liquidity at fairly long maturities. Given the experience under quantitative easing, banks are also more willing to use the discount window. 
Figure 4. Japan: Monetary Policy And Financial Conditions

Monetary conditions remain accommodative ...

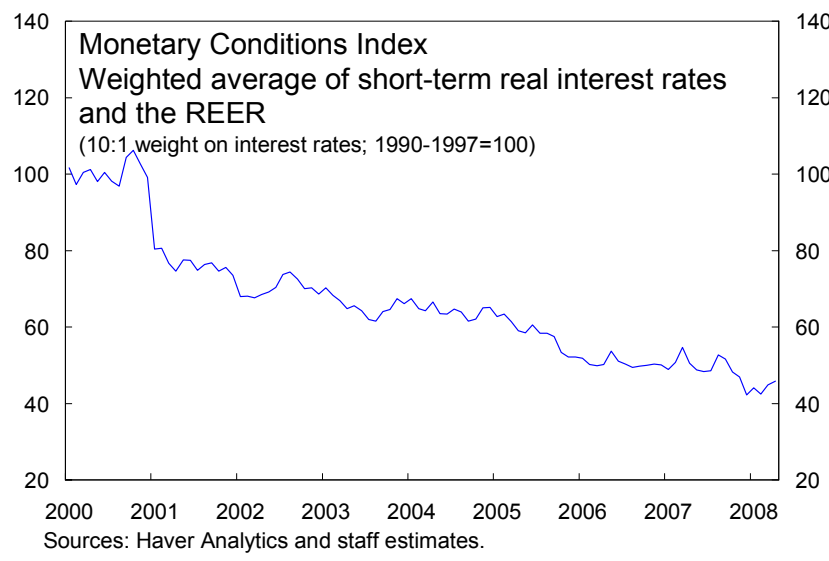

... and broader measures of financial conditions do not point to significant tightening.

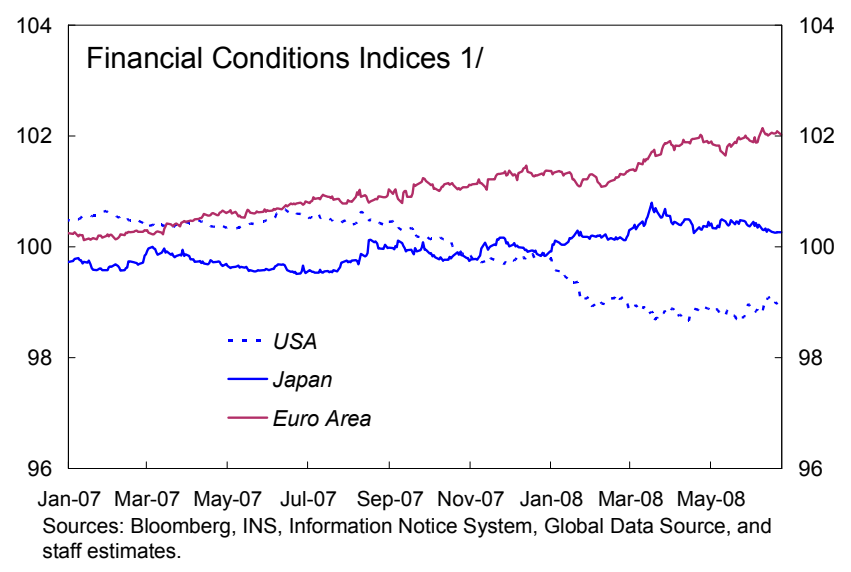

... which markets started to price-in once concerns about the severity of the global slowdown moderated ...

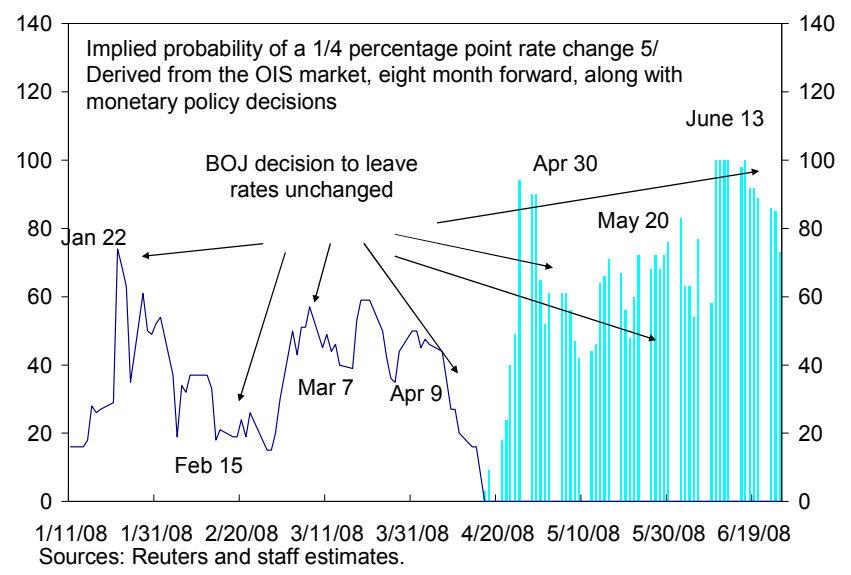

... despite the recent appreciation of the REER ...

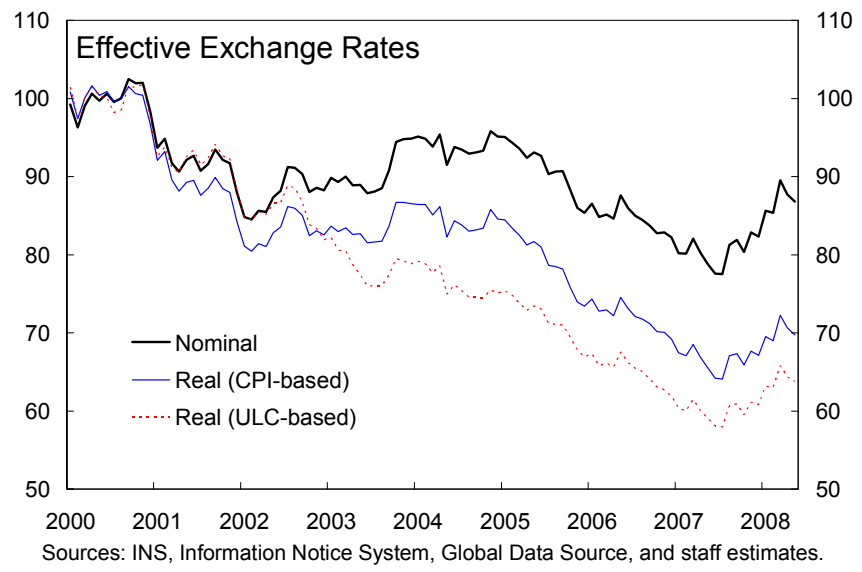

A model-based assessment of monetary stance points to future interest rate increases ...

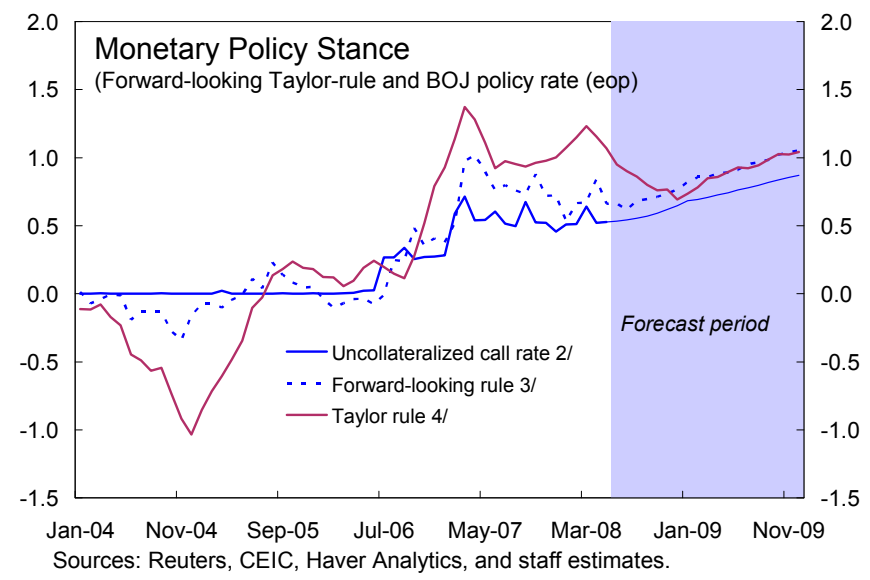

... pushing long-term JGB yields higher amid an unwinding of the earlier flight to quality.

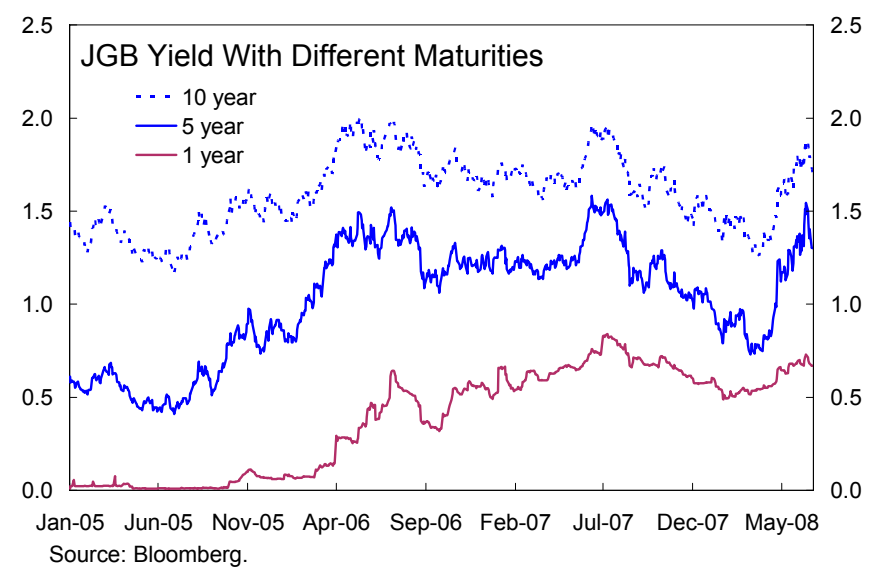

1/ Weighted average of nominal effective exchange rate, overnight LIBOR, 3-month LIBOR, 10-year government bond rate, and corporate BBB bond rate.

2/ Forecast is based on OIS data.

3/ Kuttner and Posen (2004), "Difficulty of Discerning What is Too Tight: Taylor Rules and Japanese Monetary Policy," The North American Journal of Economics and Finance, 15(1), pp 53-74.

4/ Coefficients 0.5 on the output gap and 1.5 on the deviation of inflation from its target.

$5 /$ Line represents the probability of a $1 / 4$ percentage point rate cut while bars represent the probability of a $1 / 4$ percentage point rate increase. 


\section{Box II. Japan: Developments Regarding the BoJ's Monetary Policy Framework}

Since the exit from quantitative easing in March 2006, the BoJ's Policy Board has based its monetary policy decisions on the assessment of economic developments from two perspectives: (i) the first perspective involves analysis of the most likely outlook for economic activity and prices 1-2 years ahead (i.e., currently through FY2009), while (ii) the second perspective assesses a broad variety of risks to the outlook, including low-probability but high-cost events (such as asset bubbles) over a longer time horizon. Monetary policy decisions are guided by the Board Members' "understanding of medium- to long-term price stability," which is currently defined as CPI inflation ranging between 0 and 2 percent. This understanding of price stability is not an inflation target. Instead, it is the range of inflation outcomes that each member of the Policy Board considers consistent with price stability.

The Board has enhanced its monetary policy framework in response to increased uncertainty about the future path of output and inflation. Higher commodity prices are generating cost-push inflation, while the associated loss of income together with the global economic downturn is dampening activity. In order to communicate better its views and guide inflation expectations, the Board has modified its communication policy:

- The median of the Board Members' understanding of price stability is now more clearly centered around 1 percent.

- The discussion of risks in the Outlook report has been expanded to include detailed risk-balance charts. These riskbalance charts are averages of probability distributions for growth and inflation as perceived by individual Policy Board members. In contrast, the fan charts published by inflation-targeting central banks such as the Bank of England or by the IMF's World Economic Outlook present a range of uncertainty around a single

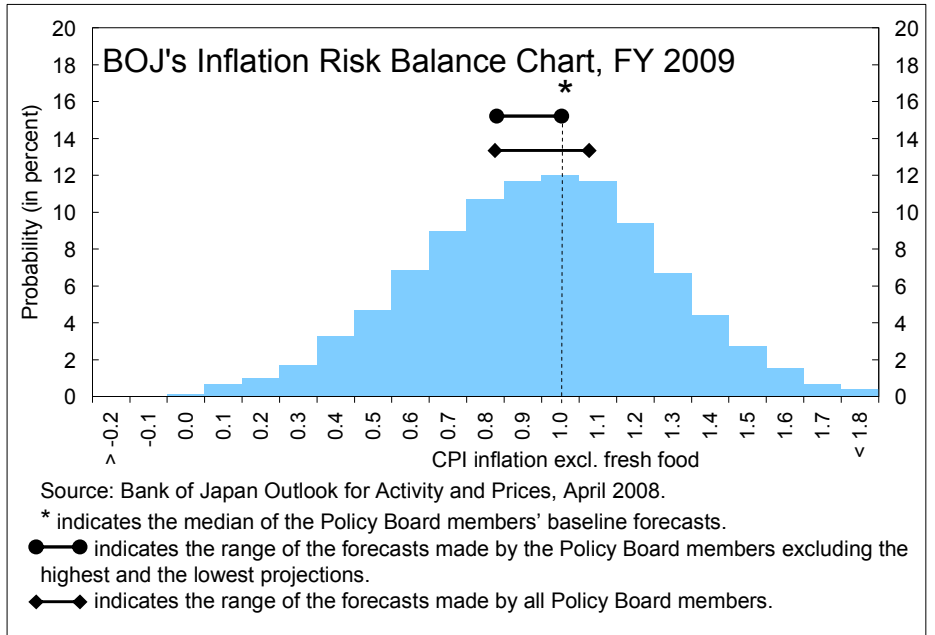
central forecast.

The monetary policy framework and monetary management tools have performed well. Japan's money markets remained stable during the recent global market disruptions in part because the BoJ has at its disposal a broad variety of tools to provide liquidity. In addition, in the conduct of monetary policy, the second perspective allows the Bank to assess signs of any asset price imbalances. This practice reflects Japan's experience with its own stock price and real estate bubbles of the 1980s, which developed in a low-inflation environment. In this regard, the BoJ's monetary policy framework already includes some of the recommendations that were floated in the recent policy debate on how central banks should respond to emerging financial bubbles. ${ }^{1}$

\footnotetext{
${ }^{1}$ For example, the April 2008 World Economic Outlook makes the case that central banks should lean against rapid asset price movements. For a more general discussion, see White, W., "Procyclicality in the Financial System: Do We Need a New Macrofinancial Stabilization Framework?” BIS Working Paper 2006/193.
} 


\section{The yen remains undervalued relative to longer-term fundamentals.}

- $\quad$ Exchange rate. Continued wide interest rate differentials and a fading home bias have led to large capital outflows over the last few years that have depressed the value of the yen (Figure 5). ${ }^{6}$ The paring back of yen-financed risk positions in the aftermath of the subprime crisis caused some of these outflows to abate. Nevertheless, the yen remains below its 2002 level in real effective terms, and by staff projections, at current levels would lead over the longer term to a current account surplus above that consistent with economic fundamentals. ${ }^{7}$

- $\quad$ Market views. Market forecasts of exchange rates five years ahead suggest only a small appreciation of the yen in real effective terms. The expected change in the real effective exchange rate implied by forward interest rates is now $3 \frac{3}{4}$ percent, compared with 11 percent last year. On a bilateral basis, the yen is expected to be around 100 against the U.S. dollar by 2013, although there is a wide range of uncertainty surrounding this assessment.

- Intervention policy. The authorities have not intervened in the foreign exchange market since March 2004. Nonetheless, foreign reserves have increased to about $\$ 1$ trillion on strong valuation gains and interest earnings. This has raised political pressure for setting up a Sovereign Wealth Fund (SWF) to manage a portion of Japan's reserves. The authorities oppose this idea given that the reserve build-up was financed by issue of short-term yen borrowing which implies that reserves do not constitute net sovereign wealth.

\section{Policy Issues and Staff Views}

\section{Given the uncertainties surrounding the outlook, the BoJ's "wait and see"} approach is appropriate. The Policy Board is correctly keeping monetary policy on hold until concerns over the outlook ease. Moreover, inflation expectations appear to be contained. The BoJ has in the past expressed a strong desire to normalize interest rates amid concerns that too much monetary accommodation for a protracted period of time could distort expectations and lead to excessive risk taking (the second perspective). However, there are no indications of such excessive risk taking so far, nor are there signs of a bubble in financial or real estate markets. From a global perspective, given the declines in investors' risk appetite that have followed the subprime crisis, the risks that continued low interest rates in Japan fuel further carry trades, weaken the yen, and complicate monetary management elsewhere, have diminished.

\footnotetext{
${ }^{6}$ The role of capital flows in the yen-U.S. dollar dynamics was analyzed in IMF Country report No. $07 / 281$.

${ }^{7}$ According to the IMF's Consultative Group on Exchange Rates (CGER), the yen is estimated to be undervalued relative to its longer-term value, although the range of undervaluation has narrowed somewhat since the last Article IV consultation.
} 
Figure 5. Japan: Exchange Rate and Capital Flows

The yen appreciated significantly against the U.S. dollar as noncommercial traders liquidated their short yen positions ...

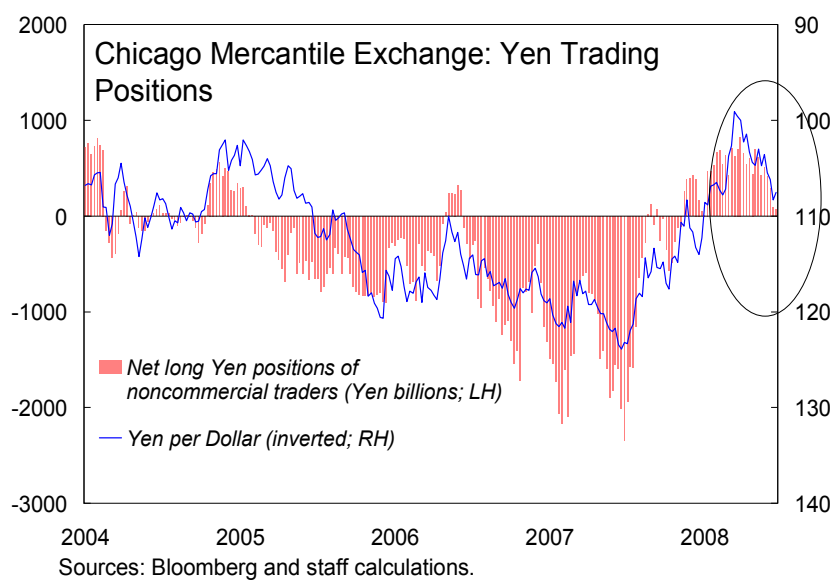

... as the risk-adjusted returns on carry currencies have declined.

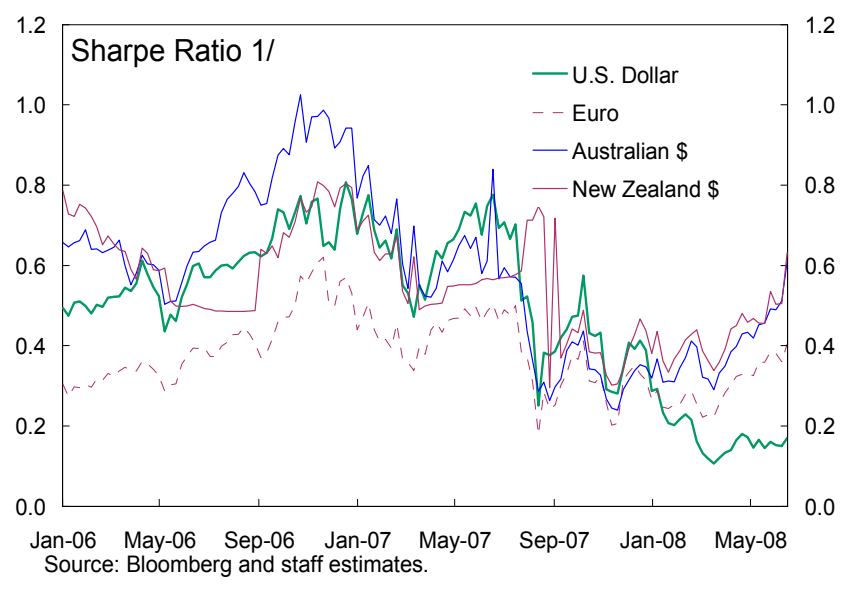

... confirming longer-term trends.

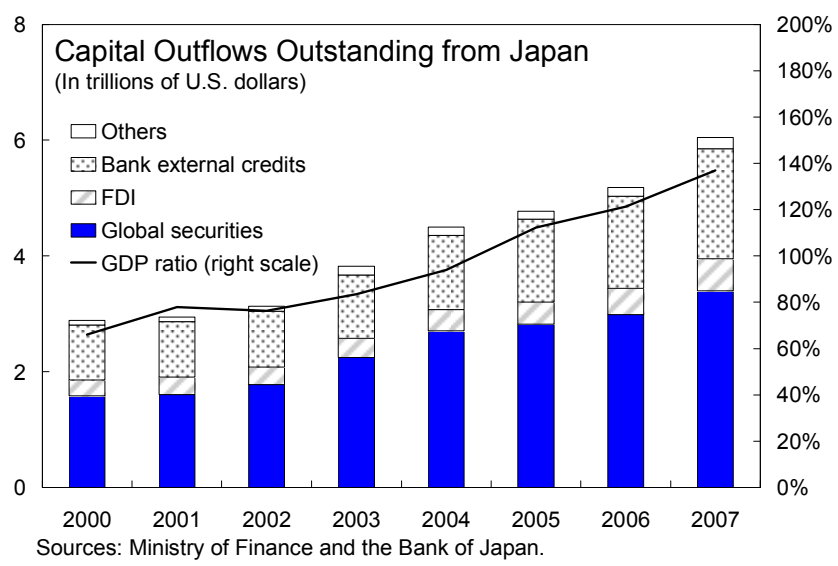

... and carry trades by FX margin investors came off their peak last summer ...

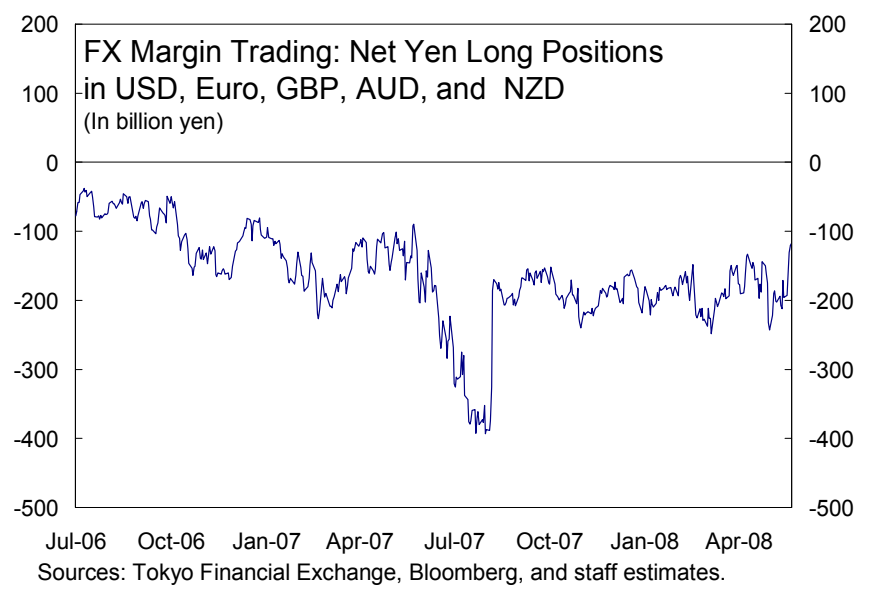

However, structural outflows from Japan have continued ...

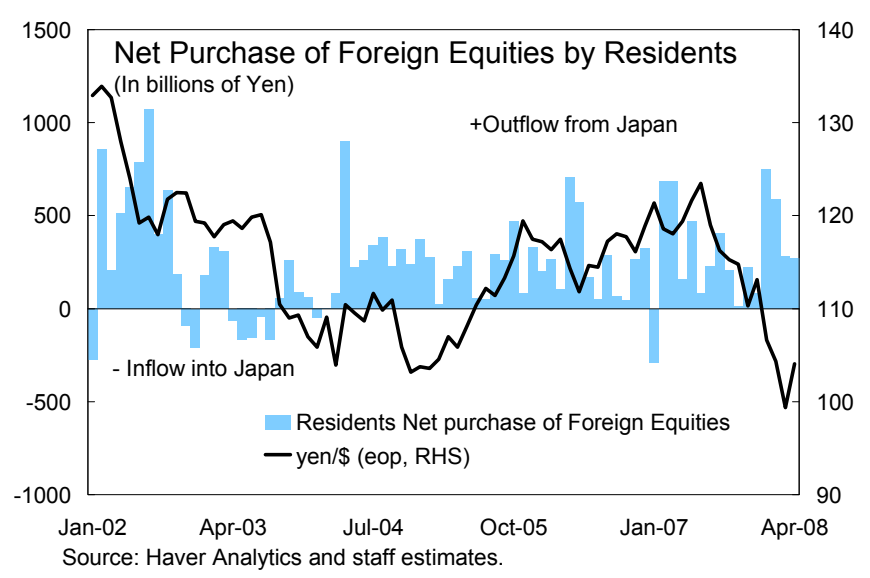

The yen has weakened more recently, although the wide distribution of forecasts points to large uncertainties ahead.

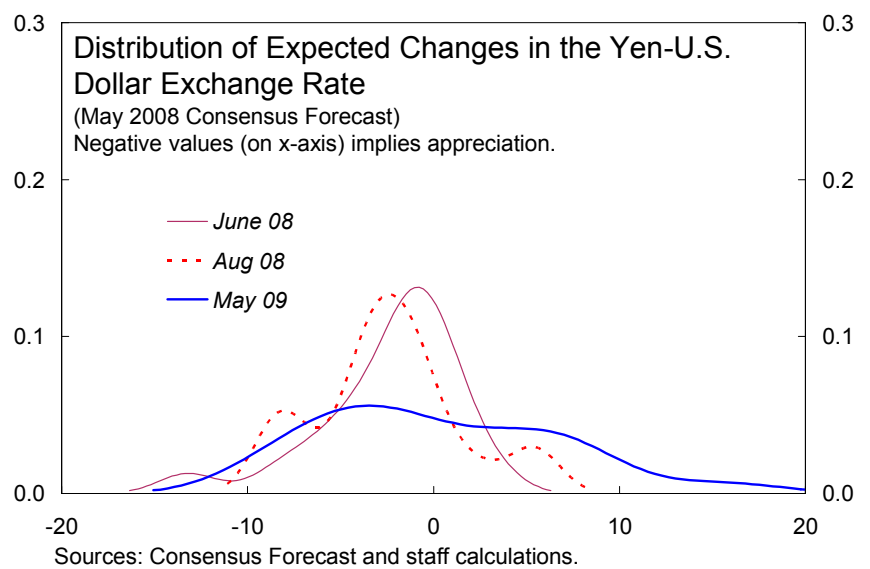

1/ The Sharpe ratio (defined as the 1-month interest rate differential divided by implied volatility in bilateral exchange rate) is a measure of the risk adjusted return on yen carry trade. 
15. Nonetheless, monetary policy action might be required under the alternative scenarios. In the case of a sharper than expected growth slowdown, the BoJ could ease, although with the policy rate already low at 50 basis points, its firepower would be limited. Alternatively, under the global inflation scenario, the BoJ might need to consider normalizing interest rates at a faster pace than warranted by domestic factors alone, especially if rising interest differentials were to lead to a weaker yen.

16. Recent steps to enhance the communication strategy are welcome. Given that firms have finally begun to pass through cost increases to consumers, guiding inflation expectations has become more challenging. The greater discussion of the risks to the outlook and of the views of the Policy Board Members on growth and CPI inflation in the BoJ's April Outlook should be useful in enhancing public understanding of the future conduct of monetary policy. In addition, in the staff's view the increased emphasis on the 1 percent median of the "understanding of price stability" could help anchor inflation expectations.

17. The BoJ's liquidity management has kept money markets stable. While liquidity pressures have been less pronounced than in other countries, the BoJ's more frequent and larger liquidity provisions have helped ensure market stability. That said, there may be scope to strengthen monitoring of the overall financial system by expanding information sharing between the BoJ and the Financial Services Agency (FSA) on activities of systemically important financial institutions outside the banking system, particularly regarding the liquidity positions of securities firms and the off-balance sheet exposures of nonbanks.

\section{The exchange rate should continue to be market determined.}

- $\quad$ The exchange rate. The yen is expected to appreciate in real effective terms over the longer term and the current account surplus to narrow. This adjustment would be facilitated by far-reaching structural reforms that promote a broad-based increase in productivity and the return to capital. Such reforms, which would reinvigorate domestic demand and capital inflows, should support a strengthening of the yen over time and a slower accumulation of net foreign assets as capital flows related to Japanese investors' international diversification of assets wane. Moreover, as the population ages, households' savings will fall and private investment will rise as firms substitute capital for labor, contributing to a narrowing of Japan's current account surplus.

- $\quad$ Intervention. In the event of excess volatility and disorderly movements in exchange rates, a case could be made for intervention. In general, such intervention is more likely to be effective if coordinated with other major countries.

\section{The Authorities' Responses and Policy Intentions}

19. BoJ officials provided more background about current policy issues. 
- $\quad$ Near-term monetary policy stance. BoJ officials agreed that inflation expectations were contained and considered it unlikely that inflation would rise beyond the understanding of price stability. Even so, they would watch closely for a possible steepening of the Phillips curve in light of the changes that seemed to be occurring in firms' price-setting behavior. The authorities concurred about the absence of growing imbalances under the second perspective, but noted that because such risks were longterm, the gradual normalization of interest rates should resume once downside risks to activity receded.

- Risks from the global economy. While the BoJ is likely to be flexible in the event of a severe downturn, the required monetary policy action in the case of the global inflation scenario was less certain. Higher global inflation that led to monetary tightening elsewhere would widen interest rate differentials and could weaken the yen. However, that alone would not justify a monetary response in Japan unless it also caused a change in the domestic outlook.

- $\quad$ Communication. The BoJ continues to strive for better communication policies. BoJ officials considered the risk balance chart in the April outlook report to be a useful tool for improving monetary policy transparency and communicating the Board members' views on the outlook for prices and output.

\section{BoJ officials regarded their monetary framework to be well suited to handle} disruptions in money markets. Although subprime exposure was limited, Japan had not been insulated, which illustrated how integrated global financial markets had become. In responding to market pressures, the BoJ had fallen back on the flexible tools that it had tested during the banking crisis in the 1990s and period of quantitative easing. The BoJ was able to share some of this experience with other central banks wrestling with the subprime fallout. With regard to possible gaps in financial sector monitoring, BoJ officials explained that informal sharing of information about non-bank financial institutions with the FSA was already occurring. Formally expanding such information sharing could create a false expectation that the BoJ would be a lender of last resort for these institutions.

\section{The authorities again voiced skepticism about current account-based estimates of} "equilibrium" exchange rates and reaffirmed their commitment to a market determined exchange rate. The authorities maintain their view that a methodology such as the CGER does not fully account for capital flows, a serious omission in the case of Japan given the structural outflows underway. Moreover, they continue to believe that this type of methodology overplays the role of the exchange rate in current account adjustment, again a weakness for Japan where income flows from foreign asset holdings have become the main component of the current account surplus. Disagreements about equilibrium exchange rates aside, the authorities could see no case for intervention in the foreign exchange market as long as conditions remained orderly, consistent with the recent G7 communiqué. 


\section{Policies to Safeguard Financial Stability}

\section{Background}

\section{Challenges for the financial sector include reducing banks' exposure to equity and strengthening regional banks.}

- $\quad$ Major banks. In FY2007, major banks' net profits are estimated to have declined by nearly a third due to subprime-related losses and higher loan-loss reserves. Core earnings fell by 4 percent amid compressed margins and declines in fee income. Falling share prices reduced by about 60 percent the unrealized equity gains on stockholdings (representing two-thirds of Tier 1 capital). Major banks also have significant exposures to structured products excluding subprime (estimated at around $\$ 177$ billion) where write-downs so far have been limited. Rising defaults and credit spreads could lead to additional losses, including on hedges through CDS contracts and monoline insurers.

- $\quad$ Overseas lending. With domestic interest rates expected to remain low, Japanese banks have increasingly turned abroad. Overseas lending grew by 23 percent (y/y) in 2007 with the subprime crisis apparently creating opportunities as European and U.S. banks pull back.

- $\quad$ Regional banks and SMEs. After showing steady improvement over the past few years, NPL ratios for regional banks have stopped declining, and at 4 percent are more than twice as high as for major banks. Regional banks are more exposed to the difficulties in the SME sector where bankruptcy rates are rising (Figure 6).

- Japan Post. As scheduled, Japan Post was transformed into a joint-stock company wholly owned by the government in October 2007. Japan Post's potential entry into retail banking has prompted some regional banks to form partnerships or merge.

\section{Policy Issues and Staff Views}

23. Financial sector policies are appropriately focused on guarding against spillovers from the global market turmoil. In addition to providing exceptional liquidity, the authorities have taken a number of useful steps that have helped support market confidence including disclosing banks' subprime holdings. Looking ahead, the following policy priorities - consistent with those recommended by the FSF - would further strengthen the financial system.

- $\quad$ Enhanced transparency. Greater disclosure of structured holdings, including on the underlying assets and hedging coverage, and of off-balance sheet vehicles would strengthen market confidence and discipline. Consideration could also be given to extending enhanced disclosure to nonbanks, such as insurers, with the understanding that the accounting and regulatory treatments may differ from banks. 
Figure 6. Japan: Financial Sector Vulnerabilities

Financial CDS spreads have receded from their March peak but remain elevated...

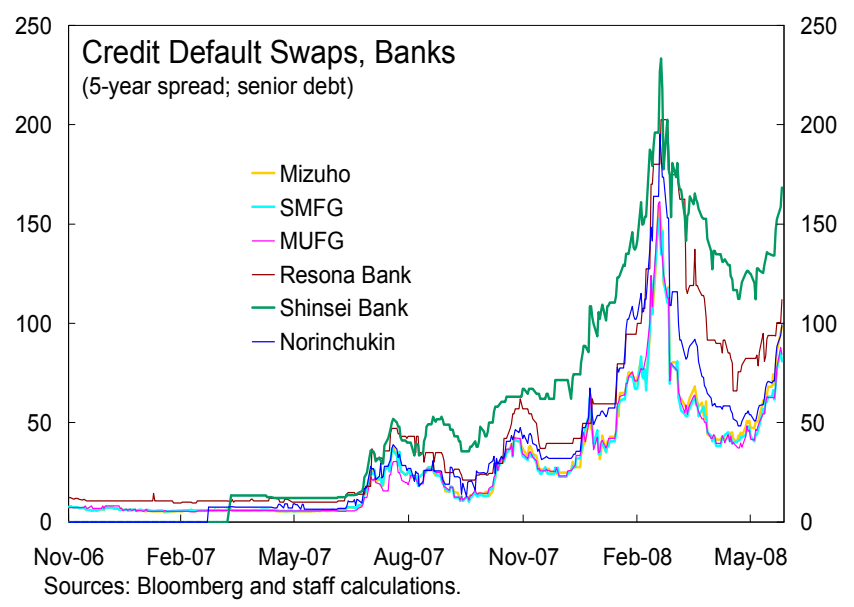

Banks continue to face significant market risk from their large shareholdings ...

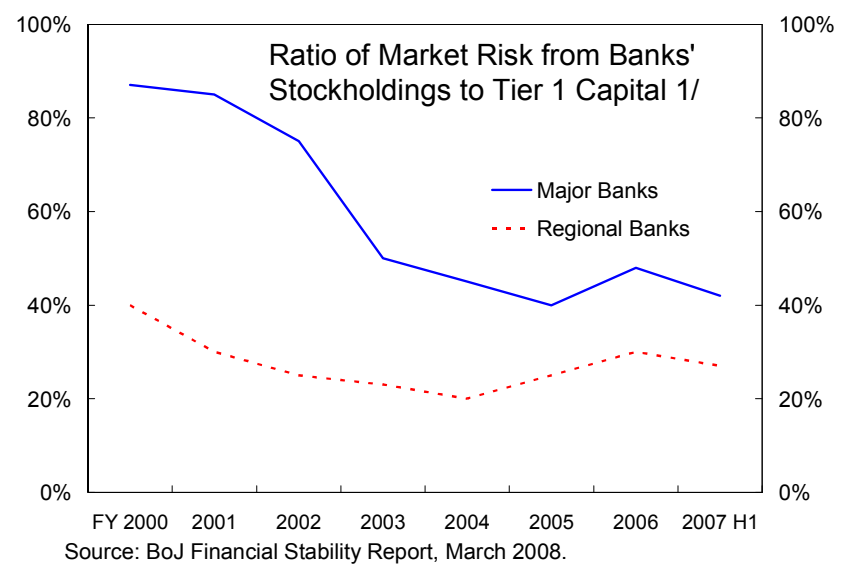

NPL ratios have come down, but remain higher at regional banks ...

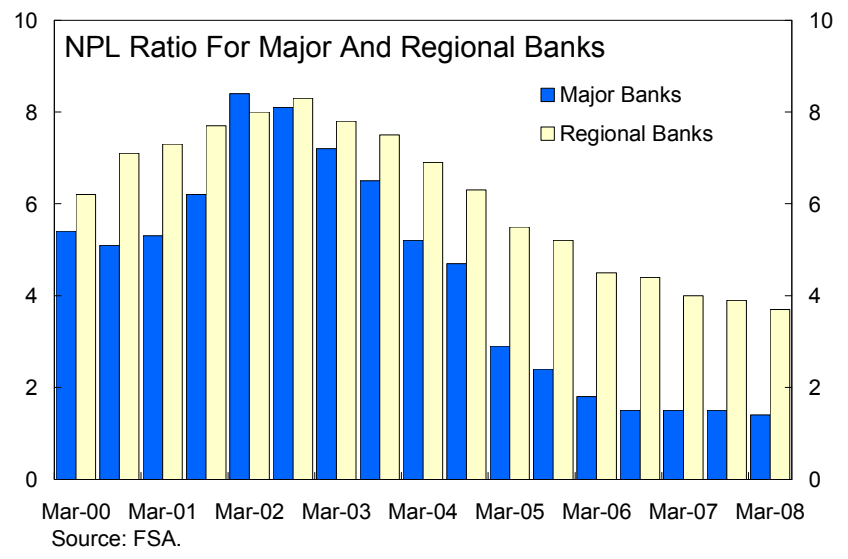

... especially for consumer finance companies whose profitability was negatively affected by the new consumer finance law.

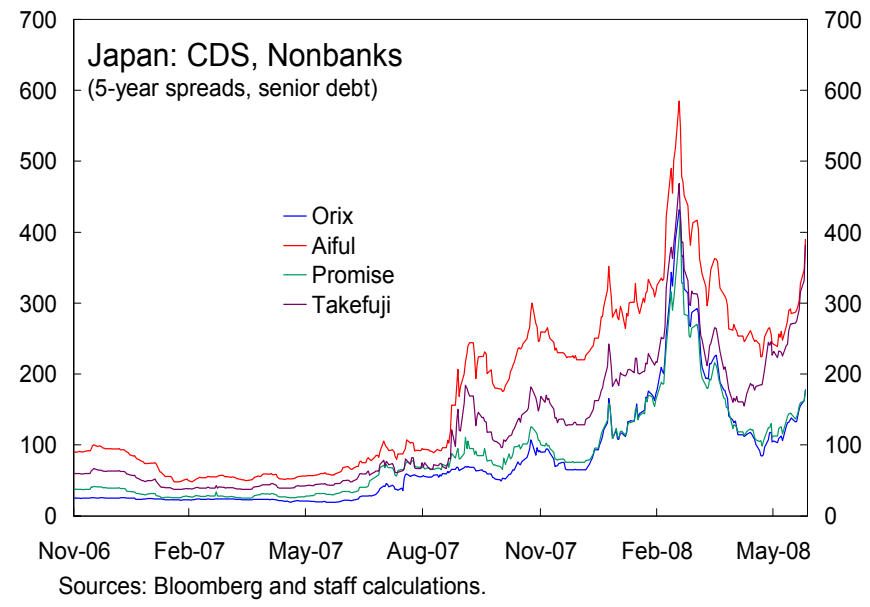

... although their lending activities abroad are enjoying robust growth.

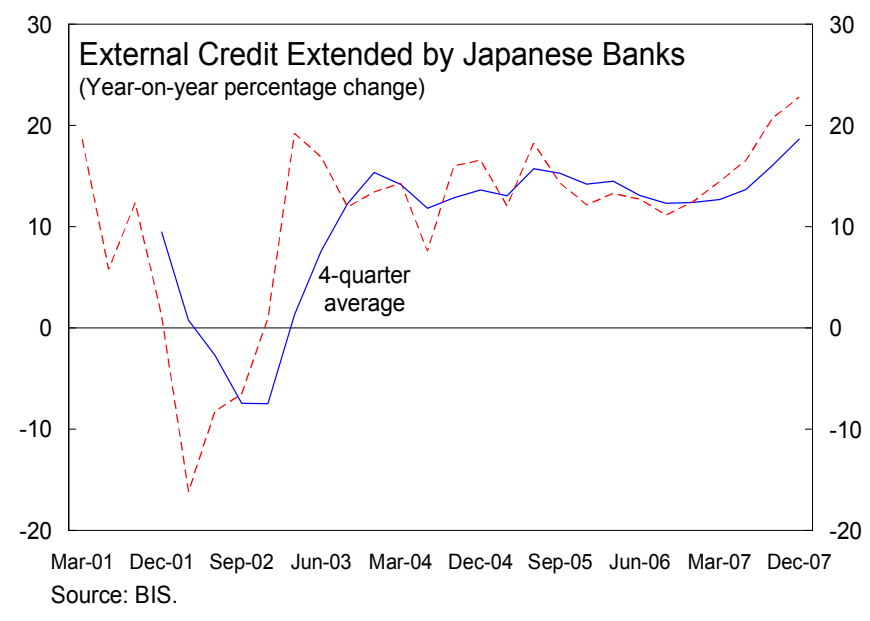

... and the rising number of bankruptcies may predict future NPLs.

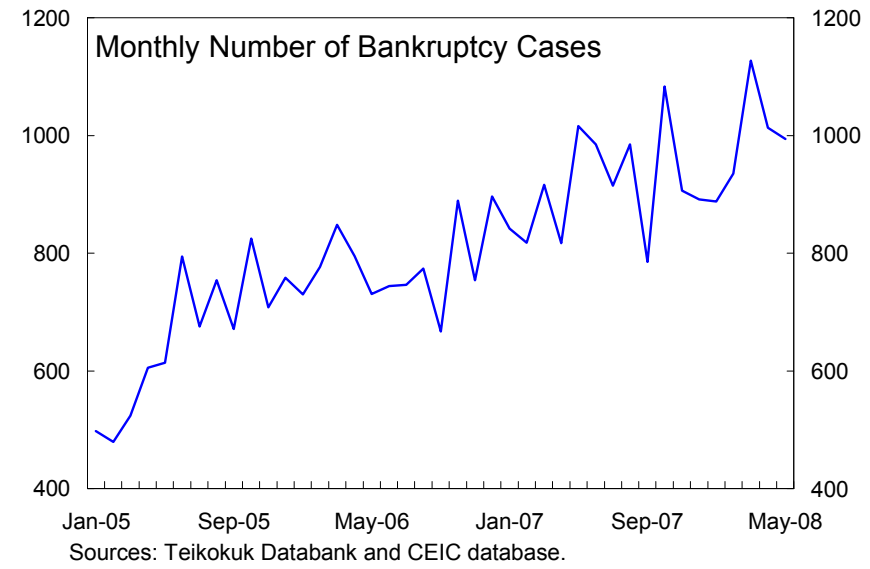

1/ BoJ estimates measured by 1-year, 99 percent VAR using the TOPIX. 
- $\quad$ Adequacy of capital cushions. Japanese major banks should be encouraged to continue efforts to improve the quality of their "core" capital as their Tier 1 capital ratios remain below those of other leading international banks. For regional banks, in light of their expansion into securities and overseas investments, consideration could be given to gradually raising the minimum capital requirement for domestic banks above the current 4 percent level. Most regional banks' capital ratios are already above 8 percent, and a higher minimum would give supervisors more flexibility in dealing with weaker banks at an earlier stage.

- $\quad$ Strengthening the market for securitization. Although securitization has grown steadily since the late 1990 s, the market remains small with the volume of secondary trading limited. Greater disclosure by the originator on the underlying assets, such as for SME-ABSs, and the creation of reliable market benchmarks (e.g., for commercial real estate) would improve price discovery and liquidity in the secondary market.

24. The financial system faces risks from a slowing economy. Widening credit spreads for low-rated companies and rising corporate bankruptcies, led by SMEs, suggest the need for vigilance against credit risk.

- $\quad$ Strengthening risk management. Supervisors need to ensure that banks, particularly regional banks, have appropriately classified and provisioned against problem loans. At the same time, having in place robust credit risk assessment systems to manage overseas portfolios will help Japanese banks to take advantage of new lending opportunities while guarding against possible risks.

- $\quad$ Reducing market risk. Banks should be encouraged to continue efforts to gradually reduce their stockholdings as part of an overall strategy for improving their risk-return profile. This reduction will be promoted by the increase in capital charge for existing equity holdings to the same level as that for new equity purchases which is set for 2014 under Basel II.

\section{Over the longer term, further reforms are needed to improve financial} intermediation and promote stability. These would include: encouraging further bank consolidation to boost core profitability; managing the privatization of Japan Post to ensure a level playing field for all institutions $;{ }^{8}$ and promoting a broader sharing of credit information to strengthen risk pricing and financial stability. Further development of the capital markets would also help enhance Tokyo's appeal as an international financial center.

\footnotetext{
${ }^{8}$ An Annex to the Selected Issues paper describes developments regarding J-Post privatization.
} 


\section{The Authorities' Responses and Policy Intentions}

\section{The authorities are closely monitoring developments in the financial sector, and are taking steps to enhance its resilience in accordance with the FSF recommendations.}

- $\quad$ Greater disclosure for structured products holdings. As recommended by the FSF, the authorities have encouraged banks under Pillar III of the Basel framework and non-life insurers to disclose more detailed information on structured holdings in their end-year reports. The Accounting Standards Board of Japan is also reviewing enhanced disclosure for off-balance sheet items, including for special-purpose companies.

- $\quad$ Adequacy of capital cushions. The authorities pointed out that raising the minimum capital requirement for domestic banks above 4 percent was not called for under the Basel framework which established a minimum capital requirement of 8 percent only for internationally active banks. Such a step might also harm already weak local economies that depend heavily on relationship-based lending by regional banks. Staff responded that the Basel framework does not preclude regulators from tightening minimum capital requirements for domestic banks if conditions warrant. Moreover, tighter standards could strengthen the overall system by encouraging a small number of weak regional banks to rebuild their capital or seek a merger. Consolidation would put regional banks in a better position to compete with Japan Post.

- $\quad$ Strengthening the market for securitization. The authorities emphasized that steps have been taken under Basel II to require rating agencies to disclose more detailed information on the underlying assets of securitized products. In 2004, a working group consisting of the $\mathrm{BoJ}$ and market participants also laid out a number of measures for strengthening the infrastructure and disclosure. That said, the authorities recognized that more should be done to enhance evaluation and trading of securitized products.

- $\quad$ Improving risk management. The FSA observed that in recent years, regional banks have strengthened their financial conditions, as shown by their improved capital and NPL ratios. While the FSA remains vigilant to regional banks in light of the slowing economy, the authorities did not view the weakening conditions of SMEs as a significant risk to the financial system as a whole, particularly when compared to the risk from a U.S. slowdown or renewed global market turmoil.

- $\quad$ Reducing market risk. The authorities noted that banks have reduced their holdings of equity, but the pace has slowed. The authorities are taking steps to encourage banks to reduce their equity risk and pointed out that the schedule for raising the capital charge for existing equity holdings is set three years earlier than for European and U.S. banks. 


\section{Structural Policies to Boost Growth}

The structural reform agenda is largely unchanged from last year and was not a major focus of this year's consultation. There is a need to increase the pace of reforms.

\section{Background}

\section{Some progress has been made in implementing structural reforms commitments} under the Multilateral Consultation, but momentum has slowed.

- $\quad$ Liberalizing product markets. The government signed economic partnership agreements (EPAs) with Brunei, Chile, Indonesia, and Thailand in 2007 and with ASEAN in 2008. While some progress has been made in expanding successful reforms outside "special zones," there has been little progress in opening up protected sectors, such as in nursing and education.

- $\quad$ Promoting inward FDI. Last year, the government allowed capital gains to be deferred in "triangular" mergers where a foreign company acquires a Japanese target via a local unit. While this facilitated Japan's first major triangular merger, foreigners still view investing in Japan as difficult as firms have taken steps to limit minority shareholder rights (e.g., through "poison pills" and cross-shareholdings).

- Labor reforms. Privately-run job placement centers have been set up on a trial basis, but the bill to extend pension coverage to temporary workers was not passed by the Diet. The government plans to revise the labor standard law to raise the minimum overtime pay and reduce overtime hours worked.

- $\quad$ Financial market development. The authorities are implementing measures to strengthen the competitiveness of Japan's financial and capital markets. The Diet amended the Financial Instruments and Exchange Act in June inter alia to enable new exchange markets exclusively for professional investors and to expand exchangetraded funds to include commodity futures.

\section{Policy Issues and Staff Views}

28. The priority should be to reinvigorate the structural reforms outlined in previous Article IV Consultations.

- Labor and product markets. Reforms to enhance labor market flexibility and participation, and further deregulation in product markets, would raise productivity and wages, particularly in the service sector, encourage firms to hire more regular workers, and hence contribute to the narrowing of dualities (Box III). 


\section{Box III. Why Are Japanese Wages So Sluggish? ${ }^{1}$}

\section{Real wages have stagnated in Japan over the past} decade. Wage growth failed to pick up during the 2002-07 expansion, widening the accumulated gap between hourly wages and productivity to about 20 percentage points. While labor income shares have declined in many advanced economies as a result of globalization and technological change (April 2007 WEO), workers' compensation in Japan has grown at an unusually slow pace compared with most other rich countries.

\section{A number of explanations have been put forward for sluggish wage growth in Japan:}

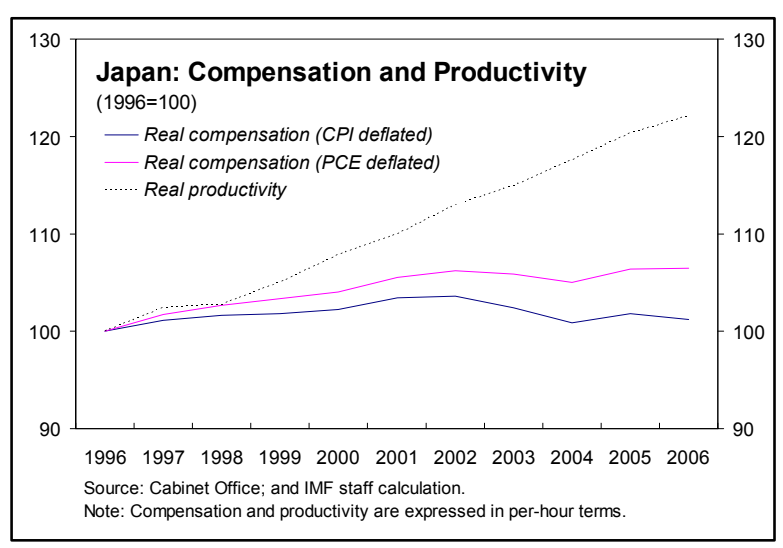

- Impact of foreign competition. Real productivity growth in Japanese manufacturing has been rapid. However, international competition has pushed down relative prices of manufactured goods, reducing nominal gains. In fact, manufacturing wages have grown at an even lower pace than nominal productivity, as internationally-competing industries have become more sensitive to cross-country wage differentials.

- Deregulation measures. Legal changes in the late 1990s expanded the list of industries which can hire nonregular workers. The large difference in employment protection and benefits between regular and nonregular workers has stimulated firms with low profitability (often in services) to offset rising input costs by offering mostly lower-paid temporary positions. ${ }^{2}$ As a result, incentives for profitable companies to agree to attractive compensation packages have been reduced.

- Population aging. The retirement of the highly-paid baby-boomers and their re-employment at lower parttime wage rates has possibly also tended to depress aggregate wage growth.

The unbalanced nature of Japan's growth may also have contributed to a more rapid decline in the labor income share than in other advanced countries. The Japanese nonfinancial services sector (two-thirds of total employment) has achieved low productivity gains relative to other advanced countries. This stands in sharp contrast with significant productivity growth in manufacturing that places Japan well above many of its peers. Since wages in manufacturing have tended to increase more slowly than productivity due to globalization and technological change, and wages in nonfinancial services have been constrained by low productivity growth, aggregate wages have trailed productivity gains. Indeed, cross-country evidence suggests that countries with sizeable differentials between manufacturing and services productivity growth have experienced the largest declines in labor income share in recent years. Reforms aimed at increasing productivity in services and reducing gaps in employment protection and benefits between regular and non-regular workers could therefore help put wages in Japan on an upward trajectory.

${ }^{1}$ A Selected Issues paper examines the factors behind Japan's sluggish wage growth in more detail.

${ }^{2}$ Non-regular workers (part-time workers, dispatched workers, etc.) typically earn about 40 percent less than regular workers, are much easier to dismiss, and have limited social insurance. The share of non-regular workers has grown from 20 percent of the labor force in 1990 to 34 percent in 2007. 
Labor market. Labor utilization would improve with more flexible work arrangements (including those aimed at raising female labor participation); easier rules for dismissal; greater portability of pensions; and more balanced employment conditions for regular and temporary workers. A more liberal and bolder approach to immigration policy would address special labor needs and shortages. In this regard, a government panel is considering recommendations for accepting more skilled professionals into Japan.

$>$ Product markets. Further deregulation and market opening in agriculture, retail, and services, would give a boost to productivity and make Japan a more attractive destination for foreign investment. In services, priorities for deregulation include transportation, network industries, the electricity sector, and gas utilities. ${ }^{9}$ Applying successful reforms in the Special Zones on a nationwide basis and opening further "government-driven" markets to the private sector could build support for deeper reforms.

29. Structural reforms would lift medium-term growth prospects and promote external stability. Under staff's baseline scenario, growth converges to potential over the medium term. This path assumes that continued efficiency gains from past corporate restructuring and $R \& D$ spending offset the negative effects of a shrinking labor force. ${ }^{10}$ However, productivity growth

\begin{tabular}{|c|c|c|c|c|c|c|c|}
\hline \multicolumn{8}{|c|}{$\begin{array}{l}\text { Japan: Medium-Term Projections, 2007-13 } \\
\text { (Percentage change from the previous period, unless otherwise indicated) }\end{array}$} \\
\hline & 2007 & 2008 & 2009 & 2010 & 2011 & 2012 & 2013 \\
\hline Real GDP & 2.1 & 1.5 & 1.5 & 1.7 & 1.7 & 1.7 & 1.7 \\
\hline Total domestic demand & 1.0 & 0.5 & 1.3 & 1.8 & 1.8 & 1.7 & 1.7 \\
\hline $\mathrm{o} / \mathrm{w}$ : residential investment (contrib.) & -0.4 & -0.1 & 0.1 & 0.0 & 0.0 & 0.0 & 0.0 \\
\hline Net exports (contribution) & 1.1 & 0.9 & 0.3 & 0.0 & 0.0 & 0.0 & 0.0 \\
\hline Unemployment rate (percent) & 3.9 & 3.9 & 4.0 & 3.9 & 3.8 & 3.8 & 3.8 \\
\hline CPI inflation & 0.0 & 1.1 & 0.8 & 1.0 & 1.5 & 1.5 & 1.5 \\
\hline \multicolumn{8}{|l|}{ Saving-investment balances $1 /$} \\
\hline Private & 5.0 & 4.0 & 3.7 & 3.5 & 3.2 & 2.9 & 2.6 \\
\hline Public & -0.2 & -0.1 & 0.1 & 0.2 & 0.3 & 0.4 & 0.5 \\
\hline Current Account Balance 1/ & 4.8 & 3.9 & 3.8 & 3.7 & 3.5 & 3.2 & 3.1 \\
\hline Trade Balance 1/ & 2.4 & 1.4 & 1.5 & 1.3 & 1.1 & 0.8 & 0.5 \\
\hline Investment Income 1/ & 3.2 & 3.1 & 2.9 & 2.9 & 2.9 & 3.0 & 3.1 \\
\hline
\end{tabular}
could be higher with further progress in structural reforms, in particular improving labor utilization, enhancing product market competition, liberalizing agriculture, and facilitating foreign direct investment.

\section{The Authorities' Responses and Policy Intentions}

30. The authorities recognized that the challenge was to speed up reforms. The authorities indicated new measures to boost medium-term growth and reduce dualities will be outlined in the 2008 Basic Policies.

- $\quad$ Raising productivity. The authorities noted that they are in the process of easing visa requirements for high-skilled workers. Measures to liberalize the aviation industry and

\footnotetext{
${ }^{9}$ Detailed reform priorities were examined in Chapter V of IMF Country Report No. 07/281.

${ }^{10}$ Both total factor productivity and the capital stock contribute around 1 percent to potential growth, while labor input contributes -0.3 percentage points.
} 
agriculture were under consideration, including reducing regulations on land usage. Japan will continue increasing the number of EPAs.

- Labor market reform. The authorities indicated that the June 2008 Basic Policies was likely to include measures such as greater childcare facilities and more flexible working hours that were aimed at raising participation by women and the elderly in the labor market.

- $\quad$ Enhancing Tokyo's appeal as an international financial center. The authorities pointed out that developing the financial system would provide households with alternative instruments for savings, help raise income, and reduce dualities. In this regard, it would be important to strengthen corporate governance. 
Table 1. Japan: Selected Economic Indicators, 2005-09

Nominal GDP: US $\$ 4,378$ billion (2007)

Population: 127.8 million (2007)

GDP per capita: US $\$ 34,272(2007)$

Quota: SDR 13,312.8 million

\begin{tabular}{|c|c|c|c|c|c|c|}
\hline & & & & & Proj. & \\
\hline & 2005 & 2006 & 2007 & 2008 & & 2009 \\
\hline Growth (percent change) $1 /$ & & & & & & \\
\hline Real GDP & 1.9 & 2.4 & 2.1 & 1.5 & & 1.5 \\
\hline Domestic demand & 1.7 & 1.6 & 1.0 & 0.5 & & 1.3 \\
\hline Private consumption & 1.3 & 2.0 & 1.5 & 1.1 & & 1.4 \\
\hline Residential investment & -1.5 & 0.9 & -9.5 & -4.4 & & 3.9 \\
\hline Business investment & 9.2 & 4.3 & 2.2 & 0.9 & & 1.7 \\
\hline Government consumption & 1.6 & -0.4 & 0.7 & 0.5 & & 0.9 \\
\hline Public investment & -10.1 & -8.1 & -2.5 & -3.2 & & -3.4 \\
\hline Stockbuilding $2 /$ & -0.1 & 0.2 & 0.1 & -0.1 & & 0.0 \\
\hline Net exports $2 /$ & 0.3 & 0.8 & 1.1 & 0.9 & & 0.3 \\
\hline Exports of goods and services & 7.0 & 9.7 & 8.6 & 8.5 & & 4.6 \\
\hline Imports of goods and services & 5.8 & 4.2 & 1.8 & 3.4 & & 4.1 \\
\hline Inflation (annual average) & & & & & & \\
\hline $\mathrm{CPI} 3 /$ & -0.3 & 0.3 & 0.0 & 1.1 & & 0.8 \\
\hline GDP deflator & -1.2 & -1.0 & -0.8 & -1.1 & & 0.4 \\
\hline Unemployment rate (annual average) & 4.4 & 4.1 & 3.9 & 3.9 & & 4.0 \\
\hline Government (percent of GDP, fiscal year basis) & & & & & & \\
\hline General government & & & & & & \\
\hline Revenue & 29.9 & 30.8 & 31.6 & 31.8 & & 32.0 \\
\hline Expenditure & 34.4 & 34.1 & 34.5 & 35.0 & & 35.1 \\
\hline Balance & -4.5 & -3.3 & -2.9 & -3.3 & & -3.1 \\
\hline Primary Balance & -3.8 & -2.7 & -1.8 & -2.0 & & -1.7 \\
\hline Primary Balance excluding social security & -3.1 & -1.6 & -0.6 & -0.7 & & -0.8 \\
\hline Public Debt, gross (calendar year basis) & 191.6 & 194.7 & 195.4 & 197.9 & & 197.3 \\
\hline Money and credit (percent change, end-period) & & & & & & \\
\hline Base money & 1.0 & -20.0 & 0.4 & -2.8 & $5 /$ & $\ldots$ \\
\hline M2 plus CDs (period average) & 1.8 & 1.1 & 1.6 & 1.9 & $5 /$ & $\cdots$ \\
\hline Domestic credit & -0.3 & -0.9 & -2.2 & -0.8 & $6 /$ & $\begin{array}{l}\cdots \\
\cdots\end{array}$ \\
\hline Bank lending (after adjustment) & 1.1 & 2.8 & 0.8 & 1.7 & $5 /$ & $\ldots$ \\
\hline Interest rate & & & & & & \\
\hline Overnight call rate, uncollateralized (end-period) & 0.00 & 0.28 & 0.46 & 0.53 & 71 & \\
\hline Three-month CD rate (annual average) & 0.06 & 0.22 & 0.51 & 0.53 & $8 /$ & $\ldots$ \\
\hline Official discount rate (end-period) & 0.10 & 0.40 & 0.75 & 0.75 & $5 /$ & $\cdots$ \\
\hline Balance of payments (in billions of US\$) & & & & & & \\
\hline Current account balance & 165.7 & 170.4 & 211.0 & 194.9 & & 195.3 \\
\hline Percent of GDP & 3.6 & 3.9 & 4.8 & 3.9 & & 3.8 \\
\hline Trade balance & 93.8 & 81.1 & 105.1 & 70.2 & & 74.8 \\
\hline Percent of GDP & 2.1 & 1.9 & 2.4 & 1.4 & & 1.5 \\
\hline Exports of goods, f.o.b. & 567.4 & 615.7 & 678.4 & 768.0 & & 801.7 \\
\hline Imports of goods, f.o.b. & 473.6 & 534.6 & 573.3 & 697.7 & & 726.9 \\
\hline Oil imports (trade basis) & 99.2 & 123.3 & 130.1 & 210.1 & & 219.6 \\
\hline FDI, net (percent of GDP) & -0.9 & -1.3 & -1.2 & -1.5 & & -1.5 \\
\hline Terms of trade (percent change) & -5.2 & -6.9 & -5.6 & -11.9 & & -1.4 \\
\hline Change in reserves & 22.3 & 32.0 & 36.5 & $\ldots$ & & \\
\hline Total reserves minus gold (in billions of US\$) & 834.3 & 879.7 & 952.8 & 982.4 & $5 /$ & $\ldots$ \\
\hline Exchange rates (annual average) & & & & & & \\
\hline Yen/dollar rate & 110.2 & 116.3 & 117.8 & 106.4 & $8 /$ & $\ldots$ \\
\hline Yen/euro rate & 137.3 & 146.0 & 161.4 & 167.6 & $8 /$ & $\ldots$ \\
\hline Real effective exchange rate $4 /$ & 71.7 & 65.1 & 60.0 & 63.8 & $7 /$ & $\ldots$ \\
\hline Real effective exchange rate (CPI-based) & 79.4 & 72.0 & 66.6 & 69.8 & 71 & $\ldots$ \\
\hline
\end{tabular}

Sources: Global Insight, Nomura database; IMF, Competitiveness Indicators System; and Fund staff estimates and projections as of June 2008.

$1 /$ Annual growth rates and contributions are calculated from seasonally adjusted data

2/ Contribution to GDP growth.

3 / Based on published annual averages of the CPI index.

4/ Based on normalized unit labor costs; $2000=100$.

5/ April 2008.

6/ March 2008.

7/ May 2008

8/ June 27, 2008. 
Table 2. Japan: General Government Operations, 2003-2008 1/

\begin{tabular}{|c|c|c|c|c|c|c|}
\hline & 2003 & 2004 & 2005 & 2006 & $\begin{array}{r}2007 \\
\text { Est. }\end{array}$ & $\begin{array}{l}2008 \\
\text { Proj. }\end{array}$ \\
\hline & \multicolumn{6}{|c|}{ (Fiscal year) } \\
\hline Total revenue & 28.0 & 28.6 & 29.9 & 30.8 & 31.6 & 31.8 \\
\hline Taxes and fines & 15.7 & 16.3 & 17.2 & 17.7 & 18.8 & 18.8 \\
\hline Social security premiums & 10.5 & 10.5 & 10.6 & 10.8 & 10.9 & 11.1 \\
\hline Property income & 1.5 & 1.5 & 1.8 & 2.0 & 1.7 & 1.6 \\
\hline Total expenditure & 35.6 & 34.0 & 34.4 & 34.1 & 34.5 & 35.0 \\
\hline Current & 30.9 & 30.7 & 30.6 & 30.3 & 31.0 & 31.4 \\
\hline Consumption & 11.9 & 11.8 & 11.6 & 11.3 & 11.3 & 11.2 \\
\hline (less) Depreciation & -2.9 & -3.1 & -3.1 & -3.1 & -3.1 & -3.1 \\
\hline Social security benefits & 15.7 & 15.9 & 16.1 & 16.2 & 16.5 & 16.9 \\
\hline Other current & 3.6 & 3.5 & 3.5 & 3.5 & 3.5 & 3.5 \\
\hline Interest paid & 2.7 & 2.5 & 2.4 & 2.5 & 2.8 & 2.9 \\
\hline Capital & 4.8 & 3.4 & 3.8 & 3.7 & 3.5 & 3.7 \\
\hline Investment & 4.3 & 3.7 & 3.6 & 3.3 & 3.1 & 3.3 \\
\hline Land acquisition & 0.6 & 0.4 & 0.7 & 0.4 & 0.4 & 0.4 \\
\hline Capital transfers & -0.1 & -0.8 & -0.4 & 0.1 & 0.0 & 0.0 \\
\hline Balance & -7.7 & -5.5 & -4.5 & -3.3 & -2.9 & -3.3 \\
\hline Primary balance & -6.3 & -4.4 & -3.8 & -2.7 & -1.8 & -2.0 \\
\hline Excluding social security & -5.7 & -4.0 & -3.1 & -1.6 & -0.6 & -0.7 \\
\hline \multirow[t]{2}{*}{ Structural balance } & -6.9 & -4.9 & -4.3 & -3.4 & -2.9 & -3.2 \\
\hline & \multicolumn{6}{|c|}{ (Calendar year) } \\
\hline Total revenue & 28.8 & 28.1 & 29.4 & 30.6 & 31.3 & 31.7 \\
\hline Taxes and fines & 16.0 & 15.9 & 16.8 & 17.6 & 18.5 & 18.8 \\
\hline Social security premiums & 10.9 & 10.4 & 10.6 & 10.8 & 10.9 & 11.1 \\
\hline Property income & 1.6 & 1.5 & 1.7 & 1.9 & 1.7 & 1.6 \\
\hline Total expenditure & 36.8 & 34.2 & 34.4 & 34.3 & 34.5 & 34.9 \\
\hline Current & 31.2 & 30.7 & 30.7 & 30.5 & 30.9 & 31.3 \\
\hline Consumption & 12.0 & 11.8 & 11.7 & 11.4 & 11.3 & 11.2 \\
\hline (less) Depreciation & -2.9 & -3.0 & -3.1 & -3.1 & -3.1 & -3.1 \\
\hline Social security benefits & 15.7 & 15.8 & 16.1 & 16.3 & 16.4 & 16.8 \\
\hline Other current & 3.6 & 3.5 & 3.6 & 3.5 & 3.5 & 3.5 \\
\hline Interest paid & 2.7 & 2.5 & 2.4 & 2.4 & 2.8 & 2.9 \\
\hline Capital & 5.6 & 3.5 & 3.7 & 3.9 & 3.6 & 3.6 \\
\hline Investment & 4.3 & 3.9 & 3.6 & 3.2 & 3.2 & 3.2 \\
\hline Land acquisition & 0.6 & 0.5 & 0.6 & 0.4 & 0.4 & 0.4 \\
\hline Capital transfers & 0.7 & -0.9 & -0.5 & 0.2 & 0.0 & 0.0 \\
\hline Balance & -8.0 & -6.2 & -5.0 & -3.8 & -3.2 & -3.2 \\
\hline Primary balance & -6.7 & -5.0 & -4.2 & -3.1 & -2.1 & -1.9 \\
\hline Excluding social security & -6.0 & -4.7 & -3.7 & -2.3 & -1.0 & -0.7 \\
\hline Structural balance & -6.9 & -5.7 & -4.7 & -3.7 & -3.2 & -3.2 \\
\hline \multicolumn{7}{|c|}{ Debt (In percent of GDP, calendar year) } \\
\hline Gross & 167.2 & 178.1 & 191.6 & 194.7 & 195.4 & 197.9 \\
\hline Net & 76.5 & 82.7 & 84.6 & 88.4 & 90.7 & 93.8 \\
\hline \multicolumn{7}{|l|}{ Memorandum items: } \\
\hline Nominal GDP (FY, trillion yen) & 493.7 & 498.5 & 503.8 & 512.2 & 515.3 & 518.7 \\
\hline Nominal GDP (CY, trillion yen) & 490.3 & 498.3 & 501.7 & 508.9 & 515.6 & 517.5 \\
\hline
\end{tabular}

Source: Fund staff estimates.

1/ Estimated from the National Income Accounts data. The fiscal year is April through March. 
Table 3. Japan: External and Financial Indicators, 2003-08

(In percent of GDP, unless otherwise indicated)

\begin{tabular}{|c|c|c|c|c|c|c|}
\hline & 2003 & 2004 & 2005 & 2006 & 2007 & $\begin{array}{r}\text { Latest } \\
2008 \\
\end{array}$ \\
\hline \multicolumn{7}{|l|}{ External indicators } \\
\hline Real exports of goods and services (percent change) & 9.2 & 14.0 & 6.9 & 9.7 & 8.6 & $\ldots$ \\
\hline Real imports of goods and services (percent change) & 3.9 & 8.1 & 5.8 & 4.2 & 1.8 & $\ldots$ \\
\hline Terms of trade (percent change) & 1.7 & -2.2 & -5.2 & -6.9 & -5.6 & ... \\
\hline Current account balance & 3.2 & 3.7 & 3.6 & 3.9 & 4.8 & $\ldots$ \\
\hline Capital and financial account balance & 1.5 & 0.3 & -2.7 & -2.5 & -4.5 & $\ldots$ \\
\hline \multicolumn{7}{|l|}{ Of which: } \\
\hline Inward portfolio investment & 1.9 & 4.3 & 4.0 & 4.6 & 4.5 & $\ldots$ \\
\hline Inward direct investment & 0.1 & 0.2 & 0.1 & -0.1 & 0.5 & $\ldots$ \\
\hline Other investment liabilities (net) & 4.4 & 0.4 & -1.4 & -4.0 & -4.7 & $\ldots$ \\
\hline Total reserves minus gold (US $\$$ billion) & 663.3 & 833.8 & 834.3 & 879.7 & 952.8 & 975.2 \\
\hline In months of imports of goods and services & 18.1 & 19.1 & 17.0 & 16.3 & 16.4 & \\
\hline Broad money $(\mathrm{M} 2+\mathrm{CDs})$ to reserves ratio & 0.9 & 0.8 & 0.8 & 0.7 & 0.6 & 0.7 \\
\hline Foreign assets of DMBs (US\$ billion) & 938.6 & 1083.6 & 1263.3 & 1190.0 & 1359.0 & $\ldots$ \\
\hline Foreign liabilities of DMBs (US\$ billion) & 683.5 & 752.6 & 831.1 & 755.6 & 733.3 & $\ldots$ \\
\hline Net international investment position (US\$ billion) & 1490.7 & 1717.3 & 1639.5 & 1849.4 & 2125.0 & ... \\
\hline \multicolumn{7}{|l|}{ Of which: } \\
\hline External loan liabilities & 721.7 & 839.0 & 860.2 & 733.9 & 721.1 & $\ldots$ \\
\hline External public sector debt (gross) 1/ & 205.6 & 319.0 & 383.2 & 422.3 & 581.0 & ... \\
\hline External loan liabilities to exports ratio & 1.4 & 1.4 & 1.3 & 1.0 & 0.9 & $\ldots$ \\
\hline External interest payments to exports (in percent) $2 /$ & 1.7 & 1.4 & 1.7 & 2.5 & 2.5 & $\ldots$ \\
\hline Nominal effective exchange rate (percent change, period avg' & 3.1 & 3.9 & -3.2 & -7.0 & -5.0 & 1.1 \\
\hline \multicolumn{7}{|l|}{ Financial market indicators } \\
\hline General government gross debt & 167.2 & 178.1 & 191.6 & 194.7 & 195.3 & $\ldots$ \\
\hline \multicolumn{7}{|l|}{ Interest rates (percent, end-year) } \\
\hline 3-month General collateral repo rate 3/ & 0.01 & 0.01 & 0.01 & 0.47 & 0.60 & 0.59 \\
\hline 3-month General collateral repo rate, real 3/ & 0.41 & -0.19 & 0.41 & 0.17 & -0.10 & -0.22 \\
\hline 3-month interest rate spread vis-à-vis U.S. & -0.89 & -2.19 & -3.88 & -4.37 & -4.36 & -1.12 \\
\hline Stock market index (TOPIX, percent change, end-year) 4/ & 23.8 & 10.2 & 43.5 & 1.9 & -12.2 & -19.8 \\
\hline \multicolumn{7}{|l|}{ Banking sector risk indicators } \\
\hline Total loans to assets (in percent) & 34.6 & 32.6 & 31.0 & 28.6 & 26.9 & $\ldots$ \\
\hline Total loans to deposits (in percent) & 81.9 & 78.8 & 78.4 & 79.5 & 77.5 & $\ldots$ \\
\hline Share of real estate sector in total lending (in percent) & 13.8 & 16.0 & 16.5 & 18.0 & 18.2 & $\ldots$ \\
\hline \multicolumn{7}{|l|}{ Share of nonperforming loans in total loans } \\
\hline (In percent, end-fiscal year) 5/ & 5.2 & 2.9 & 1.8 & 1.5 & 1.4 & $\cdots$ \\
\hline Risk-weighted capital ratio (in percent, end-fiscal year) 5/ & 11.1 & 11.6 & 12.2 & 13.1 & 12.3 & $\ldots$ \\
\hline
\end{tabular}

Sources: Global Insight, Nomura Database; IMF, International Financial Statistics; Fitch IBCA; and Fund staff estimates.

1/ Public sector debt securities and other loan liabilities.

2/ Other investment income, debit.

3/ 3-month Tokyo repo rate since October 2007.

4/ Twelve-month percent change for the latest figure.

5/ Major banks. Capital ratio is on a nonconsolidated basis. 
Table 4. Japan: Balance of Payments, 2002-07

\begin{tabular}{|c|c|c|c|c|c|c|}
\hline & 2002 & 2003 & 2004 & 2005 & 2006 & 2007 \\
\hline & \multicolumn{6}{|c|}{ (In billions of U.S. dollars) } \\
\hline Current account & 112.6 & 136.2 & 172.1 & 165.7 & 170.4 & 211.0 \\
\hline Trade balance & 92.5 & 104.0 & 128.5 & 93.8 & 81.1 & 105.1 \\
\hline Exports & 395.7 & 449.2 & 539.1 & 567.4 & 615.7 & 678.4 \\
\hline Imports & 303.2 & 345.2 & 410.6 & 473.6 & 534.6 & 573.3 \\
\hline Invisibles & 20.1 & 32.2 & 43.6 & 71.8 & 89.3 & 105.9 \\
\hline Nonfactor services & -40.7 & -31.4 & -34.3 & -24.1 & -18.2 & -21.2 \\
\hline Investment income & 65.9 & 71.3 & 85.8 & 103.6 & 118.2 & 138.7 \\
\hline \multirow[t]{2}{*}{ Net transfers } & -4.9 & -7.5 & -7.9 & -7.6 & -10.7 & -11.6 \\
\hline & \multicolumn{6}{|c|}{ (In percent of GDP) } \\
\hline Current account & 2.9 & 3.2 & 3.7 & 3.6 & 3.9 & 4.8 \\
\hline Trade balance & 2.4 & 2.5 & 2.8 & 2.1 & 1.9 & 2.4 \\
\hline Invisibles & 0.5 & 0.8 & 0.9 & 1.6 & 2.0 & 2.4 \\
\hline Nonfactor services & -1.0 & -0.7 & -0.7 & -0.5 & -0.4 & -0.5 \\
\hline Investment income & 1.7 & 1.7 & 1.9 & 2.3 & 2.7 & 3.2 \\
\hline \multirow[t]{2}{*}{ Net transfers } & -0.1 & -0.2 & -0.2 & -0.2 & -0.2 & -0.3 \\
\hline & \multicolumn{6}{|c|}{ (In billions of U.S. dollars) } \\
\hline Capital account & -3.3 & -4.0 & -4.8 & -4.9 & -4.7 & -4.1 \\
\hline Financial account & -109.5 & -115.5 & -138.5 & -144.8 & -134.7 & -224.3 \\
\hline Direct investment, net & -23.0 & -22.5 & -23.3 & -42.2 & -56.7 & -51.7 \\
\hline Direct investment abroad & -32.0 & -28.8 & -31.1 & -45.4 & -50.2 & -73.7 \\
\hline Foreign direct investment in Japan & 9.1 & 6.3 & 7.8 & 3.2 & -6.4 & 22.0 \\
\hline Portfolio investment, net & -105.8 & -97.3 & 24.6 & -12.0 & 127.4 & 68.3 \\
\hline Of which: Official & 1.7 & 5.7 & 95.1 & 52.6 & 104.6 & 177.5 \\
\hline Inflows & -86.7 & -177.9 & -173.7 & -196.2 & -71.8 & -127.2 \\
\hline Outflows & -19.1 & 80.6 & 198.3 & 184.1 & 199.2 & 195.4 \\
\hline Other investment, net & 66.0 & 192.4 & 21.1 & -68.2 & -173.4 & -204.4 \\
\hline Of which: Official & 0.2 & 8.8 & 4.1 & 25.6 & -24.8 & 0.4 \\
\hline Inflows & 116.0 & 215.3 & 8.1 & 122.5 & 57.6 & -65.9 \\
\hline Outflows & -50.0 & -22.9 & 13.0 & -190.7 & -231.0 & -138.5 \\
\hline Reserve assets & -46.7 & -188.1 & -161.0 & -22.3 & -32.0 & -36.5 \\
\hline Errors and omissions, net & 0.2 & -16.8 & -28.8 & -16.1 & -31.0 & 17.4 \\
\hline \multicolumn{7}{|l|}{ Memorandum items: } \\
\hline Nominal GDP (US\$ billion) & 3925.9 & 4237.7 & 4608.3 & 4561.1 & 4376.6 & 4378.8 \\
\hline Net foreign assets (NFA)/GDP & 39.4 & 39.4 & 39.8 & 43.9 & 49.5 & 54.0 \\
\hline Return on NFA (In percent) & 4.3 & 4.3 & 4.7 & 5.2 & 5.5 & 5.9 \\
\hline
\end{tabular}

Sources: Global Insight, Nomura database; and Fund staff estimates. 
Table 5. Japan: Balance of Payments, 2007-13

\begin{tabular}{|c|c|c|c|c|c|c|c|}
\hline & 2007 & 2008 & 2009 & 2010 & 2011 & 2012 & 2013 \\
\hline & \multicolumn{7}{|c|}{ (In billions of U.S. dollars) } \\
\hline Current account & 211.0 & 194.9 & 195.3 & 192.5 & 189.4 & 181.3 & 177.7 \\
\hline Trade balance & 105.1 & 70.2 & 74.8 & 69.6 & 57.5 & 42.9 & 30.9 \\
\hline Exports & 678.4 & 768.0 & 801.7 & 829.9 & 855.2 & 879.0 & 907.1 \\
\hline Imports & 573.3 & 697.7 & 726.9 & 760.3 & 797.7 & 836.0 & 876.2 \\
\hline Invisibles & 105.9 & 124.7 & 120.6 & 122.9 & 131.9 & 138.4 & 146.8 \\
\hline Nonfactor services & -21.2 & -16.2 & -16.5 & -21.7 & -18.3 & -21.4 & -22.0 \\
\hline Investment income & 138.7 & 152.0 & 146.1 & 153.8 & 159.3 & 168.9 & 178.0 \\
\hline Labor income & -0.1 & -0.1 & -0.1 & -0.1 & -0.1 & -0.1 & -0.1 \\
\hline \multirow[t]{2}{*}{ Net transfers } & -11.6 & -11.1 & -9.0 & -9.0 & -9.0 & -9.0 & -9.0 \\
\hline & \multicolumn{7}{|c|}{ (In trillions of yen) } \\
\hline Current account & 24.8 & 20.3 & 20.2 & 19.8 & 19.4 & 18.5 & 18.1 \\
\hline Trade balance & 12.4 & 7.3 & 7.7 & 7.2 & 5.9 & 4.4 & 3.1 \\
\hline Non-oil & 32.6 & 36.2 & 37.7 & 37.2 & 36.3 & 35.2 & 34.4 \\
\hline \multirow[t]{2}{*}{ Invisibles } & 12.5 & 13.0 & 12.4 & 12.6 & 13.5 & 14.1 & 14.9 \\
\hline & \multicolumn{7}{|c|}{ (In percent of GDP) } \\
\hline Current account & 4.8 & 3.9 & 3.8 & 3.7 & 3.5 & 3.2 & 3.1 \\
\hline Goods balance & 2.4 & 1.4 & 1.5 & 1.3 & 1.1 & 0.8 & 0.5 \\
\hline Invisibles & 2.4 & 2.5 & 2.4 & 2.3 & 2.4 & 2.5 & 2.5 \\
\hline Nonfactor services & -0.5 & -0.3 & -0.3 & -0.4 & -0.3 & -0.4 & -0.4 \\
\hline Investment income & 3.2 & 3.1 & 2.9 & 2.9 & 2.9 & 3.0 & 3.1 \\
\hline Trade balance, Customs & 0.2 & 0.1 & 0.1 & 0.1 & 0.0 & 0.0 & 0.0 \\
\hline Oil & -3.0 & -4.2 & -4.3 & -4.2 & -4.1 & -4.1 & -4.0 \\
\hline \multirow[t]{2}{*}{ Non-oil } & 3.2 & 4.3 & 4.4 & 4.3 & 4.2 & 4.1 & 4.0 \\
\hline & \multicolumn{7}{|c|}{ (In billions of U.S. dollars) } \\
\hline Capital account & -4.1 & -5.4 & -5.6 & -5.8 & -6.0 & -6.2 & -6.4 \\
\hline Financial account & -224.3 & -189.4 & -189.7 & -186.8 & -183.4 & -175.2 & -171.3 \\
\hline Direct investment, net & -51.7 & -73.3 & -76.2 & -70.7 & -68.1 & -61.4 & -58.2 \\
\hline Direct investment abroad & -73.7 & -80.9 & -84.1 & -78.8 & -76.5 & -70.0 & -67.2 \\
\hline Foreign direct investment in Japan & 22.0 & 7.7 & 7.9 & 8.1 & 8.4 & 8.7 & 8.9 \\
\hline Portfolio investment, net & 68.3 & -68.6 & -70.2 & -72.0 & -74.1 & -76.2 & -78.3 \\
\hline Other investment, net & -204.4 & -35.6 & -33.8 & -31.9 & -29.6 & -27.3 & -24.9 \\
\hline Reserve assets & -36.5 & -11.9 & -9.5 & -12.2 & -11.7 & -10.3 & -9.8 \\
\hline Errors and omissions, net & 17.4 & 0.0 & 0.0 & 0.0 & 0.0 & 0.0 & 0.0 \\
\hline \multicolumn{8}{|l|}{ Memorandum items: } \\
\hline Nominal GDP (US\$ billion) & 4378.8 & 4967.7 & 5106.2 & 5252.9 & 5434.4 & 5611.5 & 5792.0 \\
\hline Net foreign assets (NFA)/GDP & 54.0 & 51.7 & 54.0 & 56.2 & 57.8 & 59.3 & 60.5 \\
\hline
\end{tabular}

Sources: Global Insight, Nomura database; and Fund staff estimates. 


\section{Appendix I. Japan: Public Sector Debt Sustainability Analysis (DSA)}

\section{The staff has updated its} assessment of Japan's medium-term public debt sustainability. The analysis incorporates the authorities' medium-term expenditure plans and tax policy changes announced in the FY2008 budget, but is based on the staff's macroeconomic assumptions. The baseline scenario focuses on the net debt of the general government including social security.

\section{The analysis suggests that the} authorities are likely to fall short of achieving their goal of a primary balance by FY2011. The primary deficit (excluding social security) would be at 0.3 percent of GDP in FY2011. This will not be enough to stabilize the debt-to-GDP ratio over the longer term.

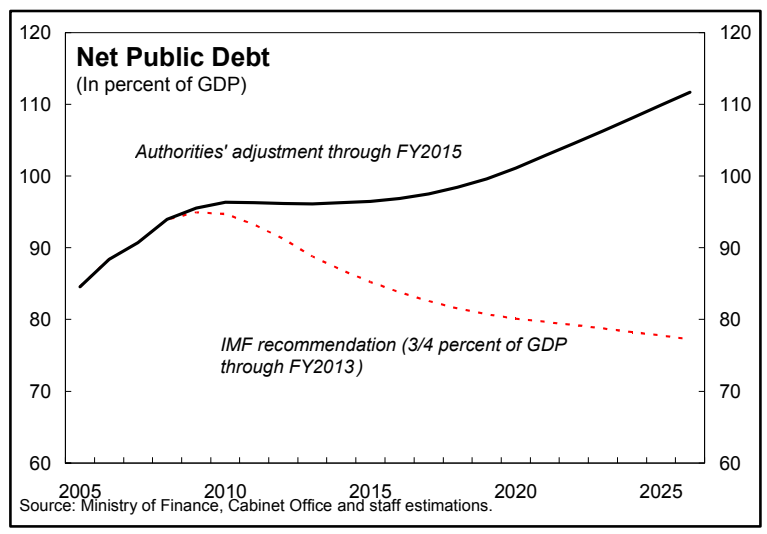

\begin{tabular}{|c|c|c|}
\hline \multicolumn{3}{|c|}{$\begin{array}{l}\text { Medium-Term Scenario: Main Assumptions 1/ } \\
\text { (Average, FY2008-11) }\end{array}$} \\
\hline & Authorities' scenario 2/ & IMF Staff \\
\hline \multicolumn{3}{|c|}{ (In percentage) } \\
\hline Nominal GDP Growth & 2.7 & 2.1 \\
\hline Real GDP Growth & 2.4 & 1.6 \\
\hline Long-term Interest Rate & 2.3 & 2.1 \\
\hline $\begin{array}{l}\text { Primary Balance in FY2011 } \\
\text { (excluding Social Security) }\end{array}$ & -0.1 & -0.3 \\
\hline
\end{tabular}

\section{The DSA underscores the sensitivity of the debt dynamics to underlying} macroeconomic assumptions and the benefits from a faster pace of consolidation. For example, with a 100 basis points increase in interest rates or a 1 percentage point decline in GDP growth from 2011 onwards, the debt-to-GDP ratio would reach around 130 percent by 2025, while under the staff's proposed scenario, the debt ratio would remain at about the same level as in FY2009 (at around 100 percent).
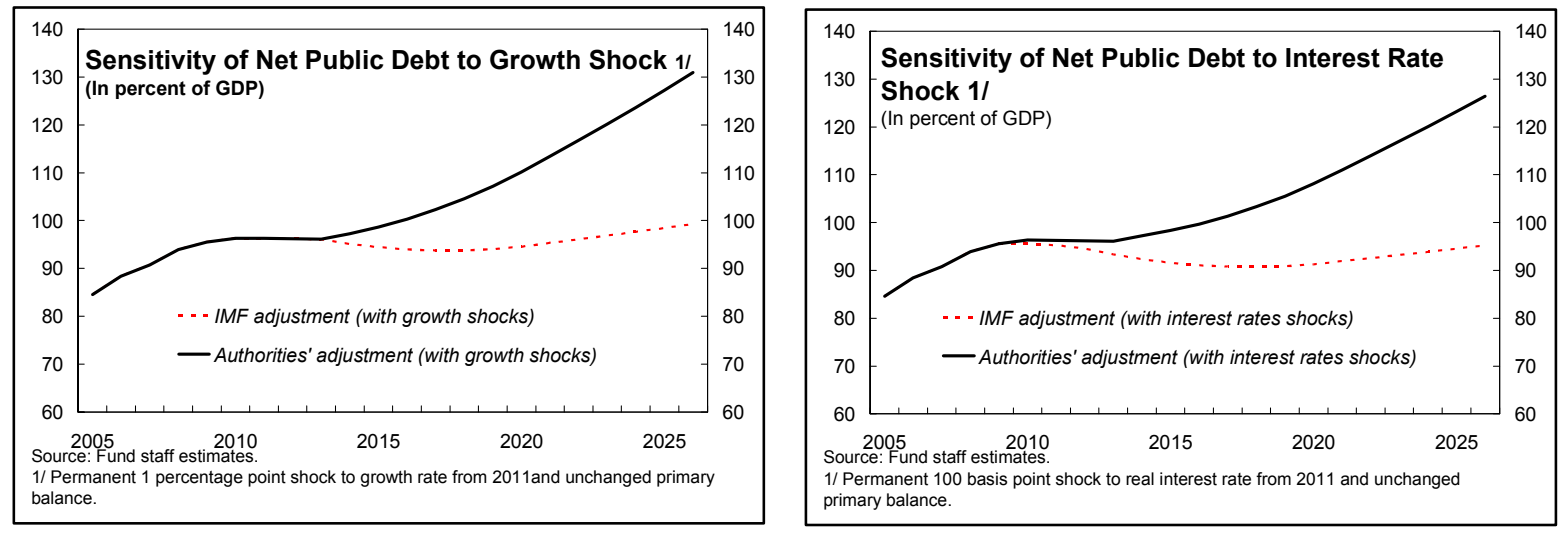


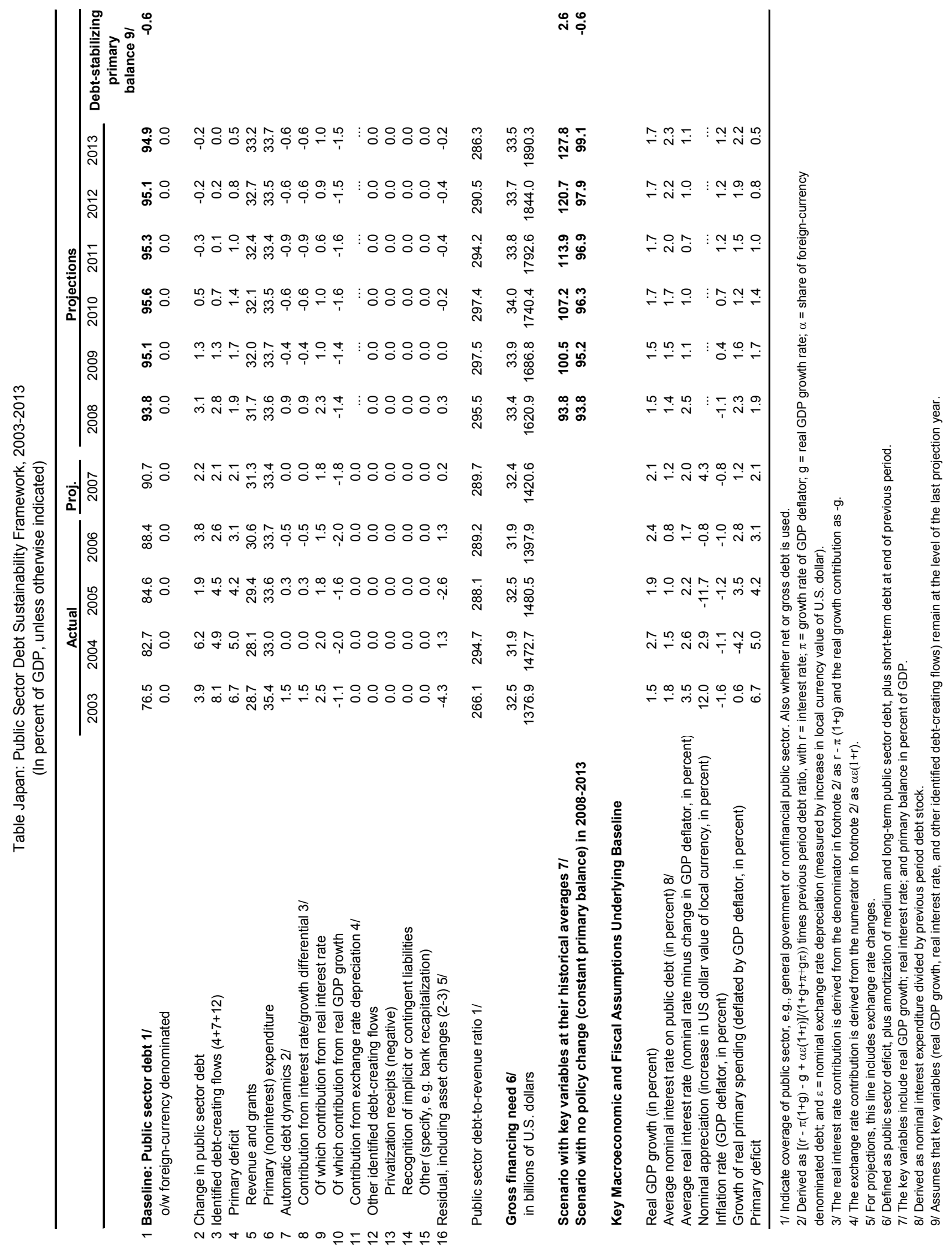




\section{INTERNATIONAL MONETARY FUND}

\section{JAPAN}

\section{Staff Report for the 2008 Article IV Consultation-Informational Annex}

Prepared by Asia and Pacific Department

(In consultation with other departments)

June 27, 2008

Contents

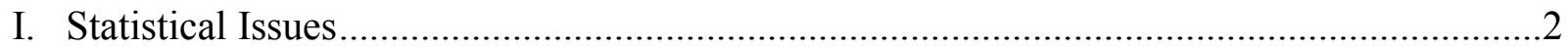

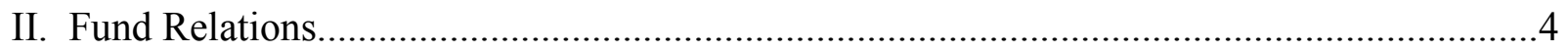




\section{ANNEX I. JAPAN-STATISTICAL ISSUES}

Statistical Issues: Economic and financial data provided to the Fund are considered adequate for surveillance purposes. Japan subscribes to the Special Data Dissemination Standard (SDDS) and meets the SDDS specifications for the coverage, periodicity, and timeliness of data. The Japanese authorities hosted a data module mission for a Report on the Observance of Standards and Codes (data ROSC) in September 12-28, 2005. The Report on Observance of Standards and Codes Data Module, Response by the Authorities, and Detailed Assessments Using the Data Quality Assessment Framework (DQAF) were published March 17, 2006 and are available at http://www.imf.org/external/pubs/ft/scr/2006/cr06115.pdf. 


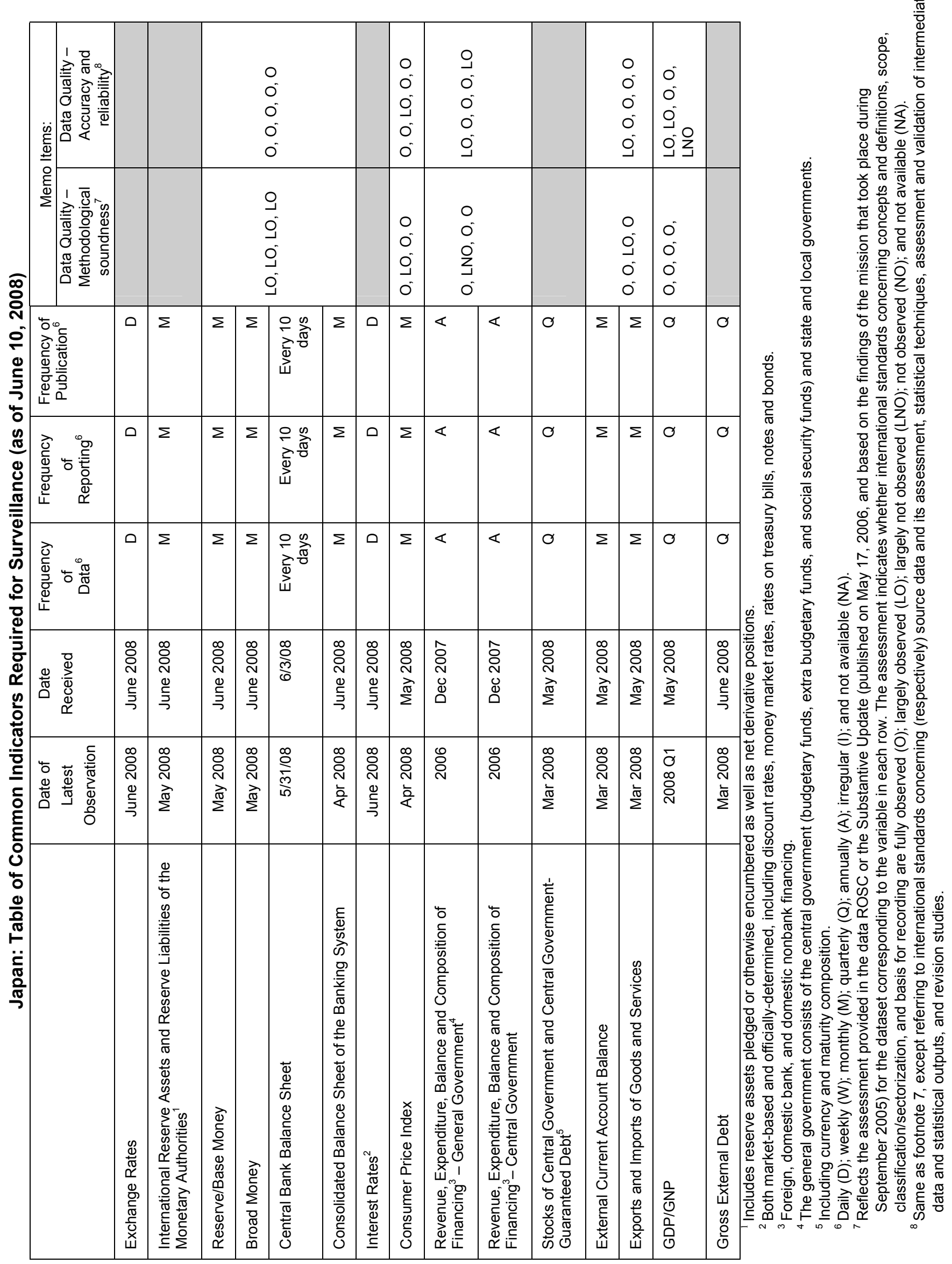


ANNEX II. JAPAN-Fund RELATIONS

(As of May 31, 2008)

I. Membership Status: Joined 8/13/52; Article VIII

II. General Resources Account:

SDR Million

Quota

$13,312.80$

\% Quota

Fund holdings of currency

$12,290.61$

100.00

Reserve position in Fund

$1,023.32$

92.32

7.69

III. SDR Department:

$\begin{array}{cc}\text { SDR Million } & \text { \% Allocation } \\ 891.69 & 100.00 \\ 1,944.39 & 218.06\end{array}$

Holdings

None

IV. Outstanding Purchases and Loans:

None

V. Latest Financial Arrangements:

VI. Projected Obligations to Fund:

None

\section{Exchange Rate Arrangement:}

Japan maintains a floating exchange rate regime. The exchange system is free of restrictions on the making of payments and transfers for current international transactions, with the exceptions of restrictions maintained against the Taliban, Al-Qaeda, the former Iraqi regime, and others, pursuant to UN Security Council Resolutions 1267, 1333, 1390, 1373, 1483, and 1532. These restrictions were notified to the Fund in accordance with Executive Board Decision No. 144-(52/51).

\section{Article IV Consultation:}

The 2007 Article IV consultation discussions were held during May 14-24, 2007; the Executive Board discussed the Staff Report (IMF Country Report No. 07/280) and concluded the consultation on July 27, 2007. The concluding statement, staff report, staff supplement, selected issues paper, and PIN were all published. 


\section{Statement by the Staff Representatives on Japan July 21, 2008}

1. This statement contains information that has become available since the Staff Report was circulated to the Executive Board on June 30, 2008. This information does not alter the staff's broad assessment of policy issues and recommendations contained in the staff report. That said, the recent renewed volatility in global markets slants the balance of risks to the growth outlook more firmly to the downside, while the continued strength of commodity prices underscores upside risks to inflation.

2. Financial markets have weakened in Japan in July, in line with global trends.

- CDS spreads for Japanese financials have risen across the board, especially for nonbank lenders (such as consumer finance companies) that rely on wholesale funding, and Japanese equities have suffered losses. However, money markets have remained stable, with the 3-month LIBOR-OIS spread steady at about 40 basis points. Despite the recent uptick in inflation, JGB yields have declined slightly, while the yen has fluctuated in line with volatility in global risk appetite.

- In light of the recent market developments, concerns have been raised about the exposure of Japanese institutions to U.S. agency bonds, particularly those issued by Fannie Mae and Freddie Mac. According to the U.S. Treasury data, total holdings of U.S. agency bonds by Japan's private and public entities (including official reserves) amounted to $\$ 231$ billion as of end-2007. Of this amount, the three largest banks, major insurers and securities firms reportedly account for about $\$ 80$ billion; for individual banks, exposures range from 5 to about 40 percent of Tier 1 capital.

3. As expected, recent indicators point to a slowdown of economic activity after a surprisingly strong GDP outturn in the first quarter. Sentiment indices (including from the Bank of Japan's June Tankan survey) continue to deteriorate as the negative impact of higher commodity prices and somewhat weaker external demand are felt. On balance, high frequency data seem broadly consistent with our projection of a soft landing to $1 \frac{1}{2}$ percent growth in calendar years 2008 and 2009. Headline inflation reached a 10-year high of 1.3 percent (y-o-y) in May on higher food and fuel prices, but underlying inflation (excluding food and energy) remains close to zero. Owing to continued commodity price pressures, our inflation forecast for 2008 (1.1 percent) is subject to upside risk and, in light of the incoming data, may be raised in the context of the ongoing World Economic Outlook exercise. The possibility of permanently higher commodity prices than assumed in the staff report would also imply some downside revision to our forecast of Japan's current account surplus and some narrowing of the estimated degree of yen's undervaluation relative to longer-term fundamentals.

4. At its monthly monetary policy meeting on July $14-15$, the Bank of Japan (BoJ) decided to keep its target rate unchanged at $1 / 2$ percent, citing a slowdown in the domestic 
economy, rising energy and material costs, and downside risks from the global economy. The median growth forecast of Policy Board members was downgraded from 1.5 percent to 1.2 percent in FY2008 (fiscal year begins April) — slightly below staff's projection of 1.4 percent - and from 1.7 percent to 1.5 percent in FY2009. Board members now forecast markedly higher inflation, with the median FY2008 forecast increasing from 1.1 percent to 1.8 percent and possible upside risks from changing inflation expectations of households and price-setting behavior of firms. In order to further enhance its communication strategy, the BoJ has decided to start releasing the assessment of economic and price developments from "two perspectives" after each monetary policy meeting and also plans to publish the Risk Balance Charts for the outlook more frequently.

5. The government released its FY2008 Basic Policies on June 27. The policy program reaffirms the government's commitment to achieving primary balance (excluding social security) by FY2011 and to comprehensive tax reform including raising the consumption tax and abolishing road tax earmarking. As expected, the document calls for measures to further open the Japanese economy (by increasing trade with EPA partners, liberalizing aviation, and revising FDI rules); improve labor market participation; and enhance productivity in services and SMEs. The program also aims to reduce regional disparities and cut $\mathrm{CO}_{2}$ emissions. Meanwhile, an expert panel at the Council on Economic and Fiscal Policy has released its recommendations for medium-term structural reforms. The main priorities set out by the panel include greater labor market flexibility and competition in the corporate sector; reform of the social security system; and better integration of Japanese regions into global markets. The staff considers that structural reforms in the areas highlighted by Basic Policies and the expert report would be very desirable. The challenge, however, is to translate these broad reform intentions into specific actions. 


\section{INTERNATIONAL MONETARY FUND}

EXTERNAL

Public Information Notice

RELATIONS

DEPARTMENT

Public Information Notice (PIN) No. 08/92

FOR IMMEDIATE RELEASE

International Monetary Fund

July 29, 2008

$70019^{\text {th }}$ Street, NW

Washington, D. C. 20431 USA

\section{IMF Executive Board Concludes 2008 Article IV Consultation with Japan}

On July 21, 2008, the Executive Board of the International Monetary Fund (IMF) concluded the Article IV consultation with Japan. ${ }^{1}$

\section{Background}

The Japanese economy has shown resilience to the U.S. slowdown and global financial turmoil. GDP grew by 2.1 percent in 2007 (above potential), down from 2.4 percent the previous year, mostly owing to lower private consumption growth and a regulatory-induced slump in construction activity. In the first quarter of 2008 , activity continued to be led by robust export demand from non-U.S. destinations, while the recovery in residential investment provided additional support to growth. CPI inflation was 1.3 percent $(y-0-y)$ in May, mainly driven by rising food and energy prices. Core inflation, which by staff's definition excludes both fuel and food prices, fell by 0.1 percent $(y-0-y)$. Wage pressures are limited and unit labor costs continue to fall on a year-on-year basis.

Japan's external position remains strong. The current account surplus rose to 4.8 percent of GDP in 2007 on the back of strong external demand and a further surge in investment income. However, in Q1, the trade balance narrowed substantially owing to the large deterioration in the terms of trade, while income inflows continued apace. The yen appreciated against major currencies, particularly the U.S. dollar through March, supported by an unwinding of carry trades and the large current account surplus. Outflows by Japanese investors continued to

\footnotetext{
${ }^{1}$ Under Article IV of the IMF's Articles of Agreement, the IMF holds bilateral discussions with members, usually every year. A staff team visits the country, collects economic and financial information, and discusses with officials the country's economic developments and policies. On return to headquarters, the staff prepares a report, which forms the basis for discussion by the Executive Board. At the conclusion of the discussion, the Managing Director, as Chairman of the Board, summarizes the views of Executive Directors, and this summary is transmitted to the country's authorities.
} 
provide an offset. The yen remains market determined and the authorities have not intervened since March 2004.

The fallout from the global market turmoil on the financial system has been limited. Money markets remain relatively stable owing to the banking system's lower exposure to subprime and other securitized products and the increased amounts and frequency of the Bank of Japan's (BoJ) liquidity operations. Subprime-related losses for banks have risen to $\$ 8$ billion, but still remain well within banks' operating profits and capital. Financial conditions for nonbank lenders relying on wholesale financing and low-rated corporates have tightened somewhat, while bankruptcies have edged up led by small and medium-size enterprises.

Fiscal consolidation has paused this year and the authorities' medium-term plans fail to build on recent progress. The FY2008 budget targets a broadly unchanged primary deficit (excluding social security) with a slight increase in total expenditures due to higher social security costs and lower tax buoyancy, while the net public debt ratio is estimated to rise to 94 percent of GDP, up from about 85 percent of GDP three years ago. The authorities' revised fiscal plans continue to target a primary balance by FY2011. Under staff's lower growth projections, the authorities' plans would be insufficient to prevent net public debt from continuing to trend up.

Monetary policy is accommodative. The BoJ has kept the policy rate unchanged at 50 basis points since February 2007, implying a drop in real interest rates given the uptick in inflation.

The near-term economic outlook is for a soft-landing, although there remain risks from the global economy. GDP growth is expected to moderate to $1 \frac{1}{2}$ percent (slightly below potential) in 2008-09 in line with lower global demand and the less favorable terms of trade. Headline CPI inflation is expected to rise, but inflation risks appear contained. Risks to the growth outlook have become more balanced in recent months, but considerable uncertainty remains.

Over the medium term, growth is expected to converge to potential (about 1.7 percent) and the current account surplus to narrow. This scenario assumes continued efficiency gains in the corporate and financial sectors and a shrinking labor force.

\section{Executive Board Assessment}

Executive Directors commended the authorities on the resilience thus far of the Japanese economy to the U.S. slowdown and global market turmoil. Timely liquidity provisions by the Bank of Japan have helped to buffer the effects of global financial pressures, while generally buoyant exports to emerging markets, strong household and corporate balance sheets, and limited financial sector subprime exposure have helped to underpin the economy's strength. At the same time, given the terms of trade deterioration and weakening domestic confidence, Directors considered the Japanese economy to be headed for a modest slowdown. While the headline inflation rate has risen in recent months, core inflation-stripped of food and fuel prices-remains around zero, and is expected to stay contained. 
While welcoming the prospect of a soft landing, Directors emphasized that the outlook remains subject to considerable uncertainty, with the recent renewed volatility in global markets tilting the risks to the growth projection more notably to the downside, and high commodity prices underscoring the upside risk to inflation. In these circumstances, Directors agreed with the authorities that monetary policy should remain accommodative-and backed by continued efforts to strengthen the financial sector-while fiscal policy should remain focused on mediumterm challenges. Structural reforms should also be reinvigorated to boost productivity and Japan's medium-term growth prospects.

Directors recognized the recent progress made with fiscal consolidation, and welcomed the authorities' continued commitment to achieving primary balance, excluding social security, by FY2011. As the downturn in the current fiscal year is expected to be modest, Directors encouraged the authorities to meet the budget deficit target even if revenues fall short. Some Directors noted that automatic stabilizers could be allowed to work in the event that growth slowed sharply.

Most Directors considered that, beginning in FY2009, larger fiscal adjustments than currently envisaged by the authorities will be required to stabilize the high public debt and make room for the fiscal costs of population aging. The limited scope for further expenditure cuts suggests that the future fiscal consolidation will need to involve steps on the revenue side. In this context, Directors saw the merits of a comprehensive tax reform, and most Directors supported consideration of an increase in the consumption tax. They regarded the government's intention to increase its contribution to the basic pension during FY2009 as a good opportunity to raise the consumption tax rate, as this could be viewed as a step supportive of the intention to ensure the funding of social security. At the same time, Directors acknowledged that accelerating the pace of adjustment at this juncture will be challenging, and some stressed the importance of fulfilling the government's present fiscal commitments in the first instance. Directors welcomed the authorities' plans to end earmarking of gasoline tax revenue for road-related spending from next year.

On monetary policy, given the low underlying inflation and the uncertain economic outlook, Directors saw little risk in delaying monetary tightening. They supported the Bank of Japan's approach of adopting a "wait and see" attitude and standing ready to respond flexibly should downside risks to economic activity materialize, or should inflation expectations worsen. Directors welcomed the Bank of Japan's enhanced communication strategy, which should strengthen public understanding of the authorities' policy intentions and help guide inflation expectations. Directors looked forward to a gradual normalization of interest rates once downside risks to growth recede.

Directors supported the authorities' policy of a market determined exchange rate. Noting that the authorities have not intervened in the foreign exchange market since March 2004, Directors supported the authorities' policy of limiting intervention to counter excessive fluctuations and disorderly movements of the exchange rate. Directors noted the staff assessment that, although the focus of macroeconomic and structural policies is appropriate, the yen remains undervalued relative to its longer-term value in real effective terms. They also recognized that capital 
outflows related to Japanese investors' international diversification of assets might continue to contribute to the yen's weakness in the near future. Directors generally noted that, over the longer term, the yen could be expected to appreciate on the back of policy reforms that are expected to yield widespread productivity gains. A number of Directors underscored the importance of incorporating structural capital account factors into current account-based analyses of the equilibrium exchange rate.

Directors welcomed the steps taken by the Financial Services Agency to enhance transparency and support market confidence, in line with the recommendations of the Financial Stability Forum. They commended the Bank of Japan for its flexible liquidity management that has helped to keep money markets stable. Directors welcomed the proactive steps taken by the authorities to monitor and disclose the exposure of the subprime losses, and underlined that greater disclosure and transparency can only serve to strengthen market confidence and discipline. Looking ahead, Directors encouraged the authorities to remain vigilant to risks from further global market disruptions. Steps to bolster capital cushions and improve risk management will further strengthen the financial system and enhance financial intermediation. Directors also welcomed the progress toward privatizing the Japan Post Bank, and supported the authorities' emphasis on achieving a level playing field.

Directors welcomed the authorities' intention to press ahead with their structural reforms outlined in the Multilateral Consultation, and incorporated in the authorities' recently released FY2008 Basic Policies program. Further reforms to increase labor market flexibility, enhance product market competition, and encourage inward foreign direct investment will lift mediumterm growth prospects and contribute to the orderly resolution of global imbalances.

Public Information Notices (PINs) form part of the IMF's efforts to promote transparency of the IMF's views and analysis of economic developments and policies. With the consent of the country (or countries) concerned, PINs are issued after Executive Board discussions of Article IV consultations with member countries, of its surveillance of developments at the regional level, of post-program monitoring, and of ex post assessments of member countries with longer-term program engagements. PINs are also issued after Executive Board discussions of general policy matters, unless otherwise decided by the Executive Board in a particular case. The staff report (use the free Adobe Acrobat Reader to view this pdf file) for the 2008 Article IV Consultation with Japan is also available. 
Japan: Selected Economic Indicators

\begin{tabular}{|c|c|c|c|c|c|c|}
\hline & 2004 & 2005 & 2006 & 2007 & $\begin{array}{l}\text { Proj. } \\
2008\end{array}$ & \\
\hline Real GDP & 2.7 & 1.9 & 2.4 & 2.1 & 1.5 & \\
\hline Private consumption & 1.6 & 1.3 & 2.0 & 1.5 & 1.1 & \\
\hline Nonresidential investment & 5.6 & 9.2 & 4.3 & 2.2 & 0.9 & \\
\hline Residential investment & 1.9 & -1.5 & 0.9 & -9.5 & -4.4 & \\
\hline Public investment & -9.0 & -10.1 & -8.1 & -2.5 & -3.2 & \\
\hline Public consumption & 1.9 & 1.6 & -0.4 & 0.7 & 0.5 & \\
\hline Stockbuilding (contribution to growth) & 0.3 & -0.1 & 0.2 & 0.1 & -0.1 & \\
\hline Foreign balance (contribution to growth) & 0.8 & 0.3 & 0.8 & 1.1 & 0.9 & \\
\hline Exports of goods and services & 13.9 & 7.0 & 9.7 & 8.6 & 8.5 & \\
\hline Imports of goods and services & 8.1 & 5.8 & 4.2 & 1.8 & 3.4 & \\
\hline \multicolumn{7}{|l|}{ Inflation } \\
\hline GDP deflator & -1.1 & -1.2 & -1.0 & -0.8 & -1.1 & \\
\hline $\mathrm{CPI}(\mathrm{SA})^{1 /}$ & 0.0 & -0.6 & 0.2 & 0.1 & 1.1 & \\
\hline $\mathrm{CPI}(\mathrm{NSA})^{1 /}$ & 0.0 & -0.3 & 0.2 & 0.1 & 1.1 & \\
\hline Unemployment rate (period average, percent) & 4.7 & 4.4 & 4.1 & 3.9 & 3.9 & \\
\hline \multicolumn{7}{|l|}{ Current account balance } \\
\hline Billions of U.S. dollars & 172.1 & 165.7 & 170.4 & 211.0 & 190.6 & \\
\hline Percent of GDP & 3.7 & 3.6 & 3.9 & 4.8 & 3.9 & \\
\hline \multicolumn{7}{|c|}{ General government balances (percent of GDP, FY) } \\
\hline Balance including social security & -5.5 & -4.5 & -3.3 & -2.9 & -3.2 & \\
\hline Balance excluding social security & -6.0 & -4.8 & -3.2 & -2.3 & -2.6 & \\
\hline Structural balance 21 & -4.9 & -4.3 & -3.4 & -2.9 & -3.2 & \\
\hline \multicolumn{7}{|l|}{$\begin{array}{l}\text { Money and credit (12-month growth rate; end } \\
\text { period) }\end{array}$} \\
\hline Base money & 4.2 & 1.0 & -20.0 & 0.4 & 0.4 & $3 /$ \\
\hline M2 (period average) & 2.0 & 1.9 & 0.7 & 2.1 & 2.3 & $3 /$ \\
\hline Bank lending $4 /$ & -1.2 & 1.1 & 2.8 & 0.8 & 2.4 & 31 \\
\hline \multicolumn{7}{|l|}{ Exchange and interest rates (period average) } \\
\hline Yen/dollar rate & 108.2 & 110.2 & 116.3 & 117.8 & 106.7 & 5/ \\
\hline Yen/euro rate & 134.5 & 137.3 & 146.0 & 161.4 & 169.5 & $5 /$ \\
\hline Real effective exchange rate ${ }^{6 /}$ & 76.3 & 71.7 & 65.1 & 60.0 & 63.8 & $6 /$ \\
\hline 3-month CD rate & 0.06 & 0.06 & 0.22 & 0.51 & 0.53 & 5/ \\
\hline 10 -year government bond yield & 1.51 & 1.39 & 1.74 & 1.68 & 1.58 & $5 /$ \\
\hline
\end{tabular}

Sources: Global Insight, Nomura database and IMF staff estimates and projections.

1/ Annual growth rates are calculated from annual averages of monthly data.

2/ Including social security, excluding bank support.

3/ June 2008.

4/ Data reflect the inclusion of foreign banks, foreign trusts banks and Shinkin banks in the monetary survey.

5/ July 21, 2008.

6/ Based on normalized unit labor costs; $2000=100$. Figure for 2008 is as of May. 